\title{
Invited review: Environmental enrichment of dairy cows and calves in indoor housing
}

\author{
R. Mandel, ${ }^{* 1}$ H. R. Whay, † E. Klement, ${ }^{*}$ and C. J. Nicol† \\ *Koret School of Veterinary Medicine, Robert H. Smith Faculty of Agriculture, Food and Environment, The Hebrew University, Rehovot 76100 , \\ Israel \\ †Department of Clinical Veterinary Science, Langford House, Langford, University of Bristol, Bristol BS18 7DU, United Kingdom
}

\section{ABSTRACT}

In recent years, an increasing number of farmers are choosing to keep their cows indoors throughout the year. Indoor housing of cows allows farmers to provide high-yielding individuals with a nutritionally balanced diet fit for their needs, and it has important welfare benefits for both cows and their calves, such as protection from predators, parasites, and exposure to extreme weather conditions. However, it also confronts cows and calves with a wide range of environmental challenges. These include abiotic environmental sources of stress (e.g., exposure to loud and aversive sound) and confinement-specific stressors (e.g., restricted movement and maintenance in abnormal social groups). Cows and calves that live indoors are also faced with the challenge of occupying long periods with a limited range of possible behavioral patterns. Environmental enrichment can improve biological functioning (measured as increased lifetime reproductive success, increased inclusive fitness, or a correlate of these such as improved health), help animals to cope with stressors in their surroundings, reduce frustration, increase the fulfillment of behavioral needs, and promote more positive affective states. Here, we review recent findings on the effect of social, occupational, physical, sensory, and nutritional enrichment on dairy cows and calves, and we assess the appropriateness and practicality of implementing different enrichment practices on commercial dairy farms. Some of the enrichment methods reviewed here may also be applied to those more extensive cattle-raising systems, where similar challenges occur.

Key words: social enrichment, zero grazing, animal welfare, low resilience behaviors

Received May 27, 2015.

Accepted November 29, 2015.

${ }^{1}$ Corresponding author: roi.mandel@mail.huji.ac.il

\section{INTRODUCTION}

Almost all dairy cattle are housed indoors, at least for some part of their life, and, in an increasing number of farms, indoor housing is practiced year round (Van Vuuren and van den Pol-van Dasselaar, 2006; Winsten et al., 2010; March et al., 2014). In continuous indoor housing systems (also referred to as "zero-grazing" systems), dairy cows are kept throughout the year in tiestall, freestall, or loose-housing cowsheds. Access to pasture is either limited or absent. In the past, continuous indoor housing of dairy cows was practiced mainly in regions where the climate was unsuitable for growing grass or too harsh for the animal. Today, with the gradual shift toward intensified farming, yearround housing is more widely practiced. It was recently estimated that zero-grazing housing will become the most prevalent farming practice in northwest European countries, such as northwest Germany and Denmark, by the next decade (Reijs et al., 2013). For example, in the Netherlands, the number of dairy cows housed indoors has tripled in the past $10 \mathrm{yr}$ (from 10 to 30\%; CBS, 2015). In the United States, more than 95\% of lactating cows are denied access to pasture (NAHMS, 2010). Other Mediterranean countries, such as Israel, now keep $100 \%$ of their dairy cows indoors throughout the year (Israeli Dairy Reform, 1999-2008). The practice of keeping cows indoors for extended periods may also result from environmental regulations aimed at reducing leaching of nitrates and phosphorus into water reserves (for example, the "Nitrates Action Programme" implemented in Northern Ireland in 2007; Nitrates Action Programme and Phosphorus Regulations, 2015-2018).

Keeping animals indoors provides some important welfare benefits for the animals, such as protection from predators and toxic plants and reduced exposure to extreme weather conditions (Schütz et al., 2010) and external and internal parasites. In addition, this practice enables the provision of a nutritionally balanced diet throughout the year (Algers et al., 2009). 
However, it also confronts animals with a wide range of challenges. These include abiotic environmental sources of stress (e.g., exposure to loud and aversive sounds such as the noise produced by milking facilities, Arnold et al., 2007, 2008; metal-on-metal clanging, Waynert et al., 1999) and confinement-specific stressors that are more likely to be associated with indoor systems (e.g., restricted movement when kept tied in their stall, when isolated at an early stage of life, or maintenance in abnormal social groups, Morgan and Tromborg, 2007). Zero-grazing systems, compared with other production systems, are also associated with higher incidence of lameness (Haskell et al., 2006) and increased risk for claw or foot problems, teat trampling, mastitis, metritis, dystocia, ketosis, retained placenta, and some bacterial infections (Algers et al., 2009). Once housed, animals are forced to make substantial changes in their time budgets (Newberry, 1993). For example, the food searching and eating times of cattle may be reduced to $4 \mathrm{~h} / \mathrm{d}$, compared with 6 to $12 \mathrm{~h}$ on pasture (Gomez and Cook, 2010), such that long periods must be occupied with a limited range of possible behavioral patterns (Hughes and Duncan, 1988). Mason and Burn (2011) argued that when the environment is too impoverished (i.e., without appropriate stimuli or substrates) or too small, the ability of the animals to perform natural behaviors and to satisfy their motivations (i.e., to fulfill their behavioral needs) is restricted. Such behavioral restrictions may result in frustration. Indicators of frustration in cattle include leg stamping (Cooper et al., 2008, although this can also be associated with attempts to cope with forced standing by alleviating strain on the legs and hoofs), nonnutritive oral behavior (e.g., tongue rolling; Ishiwata et al., 2007), and an increase in the visible percentage of eye whites (Sandem et al., 2002), although the latter was also associated with fear (Sandem et al., 2004). Persistent frustration is associated with the development of abnormal behaviors. One example is calves' redirected oral behavior toward pen mates when fed from a bucket and restricted from performing suckling behavior (Mason and Burn, 2011; Ninomiya, 2014).

Keeping animals in an environment that meets their proximate needs ("here and now," Dawkins, 1983, such as feeding, drinking, and sleeping) allows them to engage in low-resilience behaviors (also referred to as "luxury activities"; that is, behaviors that typically decrease when energy resources are limited or when the cost involved in the activity increases; McFarland, 1999), which are associated with improved welfare and long-term fitness (Held and Spinka, 2011). One example is play behavior, which drops out of the animal's behavioral repertoire in times of challenge (e.g., sickness, hunger, injury, predation risk, and thermal stress). In the majority of cases, the presence of play behavior is associated with improved welfare, and its disappearance is a reliable indicator of the transition from positive to poor welfare (Held and Spinka, 2011). In cattle, other low-resilience behaviors include grooming (Borderas et al., 2008; Fogsgaard et al., 2012, but see also opposing findings by Almeida et al., 2008) and use of automated cow brushes (Mandel et al., 2013).

One strategy that can help animals cope with stressors in their surroundings, prevent frustration, and increase the fulfillment of behavioral needs is to enrich their environment. Newberry (1995) defined environmental enrichment as an improvement in the biological functioning of confined animals resulting from modifications to their environment. Biological functioning refers to increased fitness (i.e., lifetime reproductive success), increased inclusive fitness (i.e., indirect fitness, by helping genetically related individuals such as kin to increase their fitness), or a correlate of both, such as improved health. By focusing on the biological functioning of the animal, Newberry (1995) offered a practical and objective way to measure and evaluate the effect of different environmental enrichment methods on welfare. However, compromised welfare does not necessarily result only from impaired biological functioning (Fraser et al., 1997). For example, the welfare of bucket-fed calves is reduced not by malnutrition but by an unfulfilled need to suckle (Fraser et al., 1997). For the purposes of this review, effective environmental enrichment will therefore be regarded as a modification to the management or surroundings of the animal that demonstrably improves biological functioning (Newberry, 1995), or other validated measures of welfare (i.e., those measures that are correlated with valenced experiences; Nicol et al., 2009) over and above what is achieved by following minimum management standards (e.g., European Union guidelines).

Although environmental enrichment plays an important role in maintaining the wellbeing of zoo animals (Shyne, 2006), laboratory animals (Baumans and Van Loo, 2013), and certain livestock such as pigs (van de Weerd and Day, 2009; see also EU Directive 2008/120/ EC, European Union, 2008a), its implementation on cattle farms is limited and has not coincided with the gradual shift toward year-round indoor housing and the challenges it places on cows. Considering the global increase in the number of cows and calves raised in zero-grazing systems, exploring different methods for meeting their needs (e.g., by enriching their environment) is more relevant today than ever before.

This review has 2 aims; first, we will review recent evidence of the effect of environmental enrichment on 
the welfare of dairy cattle kept indoors. Second, we will assess the practicality of different enrichment options, considering the divergent needs of calves, heifers, and cows separately when appropriate.

\section{ENVIRONMENTAL ENRICHMENT}

Bloomsmith et al. (1991) defined 5 categories of environmental enrichment: social, occupational, physical, sensory, and nutritional. Each category may contribute to the welfare of the animal in a different way. For example, social enrichment may fill the need of calves for a companion and help them to cope better with stressors in their surroundings (De Paula Vieira et al., 2012), whereas physical enrichment in the form of providing a cow with a secluded area in an individual maternity pen may fulfill its need to hide when calving or when sick (Proudfoot et al., 2014a,b). When considering the contribution of each category to the welfare of the animal, it is important to note the following. (1) That the mechanism that underlies each category of enrichment, and each method of enrichment, can be multifactorial (e.g., dam rearing involves both social and nutritional factors; Kalber and Barth, 2014). (2) Each enrichment type can have both short- and long-term effects (e.g., drinking colostrum and milk ad libitum is associated with improved weight gain at an early stage of life, but also aids in gastrointestinal-tract maturation, production of digestive enzymes, and nutrient absorption at a later stage through hormonal factors found in the colostrum; Bach, 2012). (3) Each enrichment method can contribute differently to the welfare of the animal, when applied at different stages of the production cycle, as a calf or an adult cow (e.g., the presence of a conspecific is associated with improved cognitive development in calves, Gaillard et al., 2014; but also with reduced stress during social isolation in cows, Kikusui et al., 2006). (4) The contribution of each category to the welfare of the animal can be explained by more than one mechanism [reduced stress expressed by calves that were raised in pairs, compared with singly reared calves, can be explained both by improved cognitive development, which allows better learning abilities but also by the mere presence of a conspecific (social buffering)]. (5) Some enrichment methods are limited to a certain time window (e.g., the effect of early social housing on cognitive development; Gaillard et al., 2014). The examples mentioned above, and others, will be discussed in more detail throughout the text and will serve as the first step toward developing a conceptual framework for enriching the environment of dairy cows. Such a framework could allow better understanding of cattle needs and improve the implementation of enrichment practices in dairy farms.

\section{Social Enrichment}

Social enrichment is defined as the provision of access to direct or indirect (visual, olfactory, auditory) contact with conspecifics (other individuals of the same species) or humans (Bloomsmith et al., 1991).

On most North American and European dairy farms, calves are separated from their mothers within $24 \mathrm{~h}$ of birth (Algers et al., 2009; but see also dam and foster rearing in organic farming, Kalber and Barth, 2014). Separating the dyad is stressful for both the dam and her calf and is followed by behavioral (e.g., increased calling and activity; Weary and Chua, 2000; Flower and Weary, 2003) and emotional (i.e., calves: cognitive bias test; Daros et al., 2014) responses. When carried out within $24 \mathrm{~h}$ of birth, the process is accompanied by a weaker behavioral response compared with separation at a later stage (i.e., 2 wk after birth, Flower and Weary, 2001; but see Hudson and Mullord, 1977 for behavioral distress following 5 min of calf-dam contact, and Johnsen et al., 2015 for the formation of cow-calf bond without nursing). Early separation is also done for economic (e.g., using sources of nutrition that are cheaper than feeding calves with their mother's milk, such as milk replacers or "waste" milk that cannot be sold) and management reasons (e.g., close monitoring of calves health and food consumption; minimizing the transmission of Johne's disease, Collins et al., 2010, and faster milk let-down speed, Kilgour and Dalton 1984). Following separation from the dam, calves are kept in single housing, pair housing, or group housing (3 calves or more).

\section{Contact with Conspecifics}

Calves. In farms that practice single housing, calves are reared individually in pens or hutches for 2 to $8 \mathrm{wk}$, mainly with the aim of decreasing the risk of horizontal disease transmission, but also to help farmers monitor calf milk intake and health. The association between group housing and morbidity is affected by the size of the group, with calves kept in large groups (i.e., 7 or more) being at higher risk of disease (Losinger and Heinrichs, 1997; Wells et al., 1997; Svensson et al., 2003, 2006; Svensson and Liberg, 2006). A tradeoff between single housing and group housing is pair housing, where physical contact is limited to only one other calf, and the risk of pathogen transmission is limited. A recent study compared the effect of different levels of social contact on calf health ranging from strict isolation in single housing to full physical contact in pair housing, but found no effect of degree of social contact on the level of the 5 most common pathogens present in Danish calf feces, or on the development of serum 
antibodies against the 3 most common respiratory pathogens (Jensen and Larsen, 2014). However, in indoor environments with poor ventilation and drainage, keeping calves in small groups (i.e., 3 calves per pen) or in pairs may increase the risk of respiratory disease, compared with individual rearing (Cobb et al., 2014). Acknowledging the contribution of physical contact to disease transmission, pair housing can be considered a tradeoff between individual rearing and group housing, in that it allows calves to engage in social contact while limiting disease transmission.

The need of calves for social contact with their peers is present from the first week of life (Wood-Gush et al., 1984). When given the option, they are more motivated to get access to full physical contact with their conspecifics, compared with only head contact through metal bars (Holm et al., 2002). Calves raised with full social contact (either from birth or 3 wk of age) will establish stronger bonds with their group members, compared with calves raised with limited contact (Duve and Jensen, 2011). The bonds that calves develop at an early stage will affect their social preferences as adults (Sato et al., 1993; Færevik et al., 2006; Gygax et al., 2010; Raussi et al., 2010).

Physical contact with conspecifics from an early age affects calf development; individually housed calves, compared with paired housed ones, spend less time at the feeder, visit it less frequently, and start ingesting concentrate from computerized starter feeder at a later stage (De Paula Vieira et al., 2010; see also Warnick et al., 1977, and Hepola et al., 2006). Individual rearing also reduces calves' social skills and their ability to cope with environmental stressors (De Paula Vieira et al., 2012; Jensen and Weary, 2013). They are also more fearful of unfamiliar calves (De Paula Vieira et al., 2012; Jensen and Larsen, 2014), have a higher heart rate during confrontation (Jensen et al., 1997), struggle more when restrained for blood sampling (Duve et al., 2012), and vocalize more when weaned from milk (De Paula Vieira et al., 2010). The reduced vocal response of pair-housed calves when weaned is thought to reflect the effect of social buffering (i.e., the alleviation of stress responses attributed to the presence of a conspecific, Edgar et al., 2015), which can help modulate or downregulate the effect of stressors on the homeostasis of the recipient (for a recent review, see Rault, 2012). Indeed, calves that were isolated with no companion for a period of $20 \mathrm{~min}$ were found to vocalize more, show less locomotor activity, and explore the pen less compared with those that were isolated with a companion, particularly a familiar companion (Færevik et al., 2006). Social isolation at an early stage seems to also affect calf behavior later on in life. Broom and
Leaver (1978) studied the effect of prolonged social isolation $(8 \mathrm{mo})$ on calves' behavior at the age of 8 and 20 mo. In both age groups, individually housed calves spent more time alone and had a lower social rank once introduced into a new group, compared with grouped housed calves.

An additional mechanism to social buffering that can affect the behavior of calves raised in isolation is impaired cognitive development. Individually reared calves achieved poorer performance in a color discrimination reversal-learning task than calves reared in pairs (Gaillard et al., 2014). The socially reared calves appear to be more flexible in their response to change in routine management and housing, an ability that was previously associated with improved welfare (Wechsler and Lea, 2007). One implication is that socially reared animals may be more competent in interacting with new technologies, such as robotic milking equipment and automated feeders. Indeed, De Paula Vieira et al. (2010) showed that calves raised individually were slower at learning to use a computerized starter feeder compared with calves raised in pairs. Therefore, the reduced learning ability associated with individual rearing may result from a cognitive impairment or emotional deficiency (or both). Raising calves in pairs or small groups fulfills their need for social contact with conspecifics from an early age, help to develop cognitive skills, social skills, and reduce stress-associated reactions.

Pair housing also has economic benefits. Rearing calves in pairs requires less space than individual housing, which can be used for spacing the pens further apart (i.e., lowering the chance of horizontal disease transmission), and for increasing the living area for each pair to allow greater comfort and encourage play behavior. For example, to raise 10 calves in isolation $(0.9 \times 1.8 \mathrm{~m}$ per calf, with $1 \mathrm{~m}$ of space between pens $)$, farmers need an area that is $18 \mathrm{~m}$ wide. In the same area, using pair-housing pens, farmers can increase the living space of each calf by more than $35 \%(1.35 \times 1.8$ $\mathrm{m}$ per calf instead of $0.9 \times 1.8 \mathrm{~m}$ ) and the distance between pens by more than $10 \%$ to further minimize the risk of disease transmission. Housing calves in pairs, however, requires adjustment to the feeding method to minimize food competition and decrease cross-sucking behavior (addressed below under nutritional enrichment).

Although pair housing is a promising rearing solution that balances calf health and social needs, some fundamental questions regarding the timing of its implementation remain open. Other questions concern the implications of dyad separation at a later stage of life (i.e., for either short periods such as for a husbandry 
procedure, or for long periods, such as when kept in different feeding groups). Breaking a social bond between 2 calves raised together from the first day of life (and prevented from maternal contact) may prove to be as stressful as breaking the bond between a calf and its dam bonded for a similar amount of time. To our knowledge, these questions have not been addressed yet and demand further investigation. Better understanding of calf social needs (i.e., especially in early life, when kept in isolation) will allow us to integrate more carefully their basic health and functioning, affective states, and natural living (Fraser, 2008).

A more natural rearing method that is little practiced in intensified dairy farms is to keep calves with their dams following parturition. Dam-reared calves are either kept with restricted or full contact with their dam or foster cow and often have access to other calves and adult cows. The length of the rearing period may vary from days to months according to farm management. Calves reared with their dam, compared with calves housed in groups and fed from an automatic feeder, express less abnormal oral behavior (e.g., cross suckling). Interestingly, a low cross-suckling rate was documented in both restricted (i.e., twice a day for 15 min each) and unrestricted contact with the dam (Roth et al., 2009; Hillmann et al., 2012). Dam-reared calves also struggle less when restrained for blood sampling compared with those housed singly or in pairs (Duve et al., 2012). When submitted to an isolation test, calves that have been reared with their dam show a lesser increase in salivary cortisol concentrations compared with artificially reared calves after reunion with their dam or group (Wagner et al., 2013). Rearing calves with their dam or foster cow also seems to affect their behavior later on in life (Le Neindre, 1989; Wagner et al., 2012; 2015). When faced with the challenge of integration into a new group, dam-reared heifers (either with restricted or unrestricted contact) express more submissive behaviors associated with longer duration of feeding and earlier lying activity, compared with heifers that were separated from their dam and fed through an automatic feeder (Wagner et al., 2012). In another study, 2.5-yr-old cows that had permanent access to their dams during the first 12 wk following parturition, expressed lower sympathetic and higher hypothalamicpituitary-adrenal (HPA) axis reactivity compared with cows that were fed by an automatic feeder (Wagner et al., 2015). The latter finding suggests that calves reared with their dam develop a reactive coping style later on in life (Wagner et al., 2015). However, because the efficacy of the coping style (i.e., reactive and proactive) depends on the situation or environment, the welfare implications of this finding are not yet clear.
Keeping calves with their dam is thought to be a natural rearing method that benefits from better public opinion compared with methods that involve early separation (Ventura et al., 2013). However, concerns regarding cow health (e.g., transmission of Johne's disease through contact of calves with the feces of its dam) and impaired milk ejection still exist (Kalber and Barth, 2014). Indeed, opponents of this rearing method base their arguments on the possible negative effect on calf and cow health, as well as the emotional distress that will be caused once the cow-calf bond is broken later on, and the limited ability of the industry to accommodate cow-calf pairs (Ventura et al., 2013). On dairy farms that are free of Johne's disease and can manage the logistics associated with keeping the dyad together (e.g., suitable enclosures, clean and dry environment), rearing calves with their dam could be an alternative enrichment method to pair housing that benefits from better public opinion. An alternative option that favors one side of the calf-dam dyad is to raise calves with a foster cow. The latter is suggested to allow calves to satisfy their suckling motivation and engage in social contact with adult cows and may reduce weaning stress (Kalber and Barth, 2014). However, more knowledge about this system is needed to evaluate its contribution to the welfare of calves and its possible negative effect on the welfare of the foster cow (e.g., when more than 2 calves are fed from the same cow).

Cows. Cows are grouped based on their physiological status (lactating/dry) or milk production status (low vs. high milk yield). As their status changes, they are regrouped and must form relationships with the new group members. This can be stressful. For example, regrouping destabilizes the social dynamic within the group and increases physical competition in the hours and days following regrouping (von Keyserlingk et al., 2008). Indeed, cows that enter a new group experience increased displacements from the feeding area and their eating time, lying time, number of lying bouts, and allogrooming events are reduced. In addition, milk production is reduced on the first day after regrouping (von Keyserlingk et al., 2008). Basic husbandry practices, such as reducing the stocking density in the pen (Talebi et al., 2014), using a familiar pen for regrouping the cows (Schirmann et al., 2011), or other methods such as grouping during the evening hours (compared with mornings, Boyle et al., 2012), can help lessen the negative effects of this procedure.

The ideal solution to meet the social needs of the cows would be to keep them in stable groups. This would therefore allow them to enjoy the benefits of social companionship and to benefit from social buffering, enabling better coping with stressors (Gutmann et al., 
2015). The efficacy of social buffering depends on the degree of affiliation between the interacting partners (calves: Færevik et al., 2006; cows: Gutmann et al., 2015; bulls: Mounier et al., 2006). Social buffering in cattle can be achieved via grooming behavior (i.e., licking), which depends mainly on familiarity and increases with the length of cohabitation (Sato et al., 1991). This behavior is regarded as a reliable indicator of friendship (Boissy et al., 2007) and seems to be independent of social dominance, as solicitation occurs both from dominant and subordinate cows (Sato et al., 1991; Val-Laillet et al., 2009). In addition to helping cows to stay clean (i.e., remove parasites, Guillot, 1981), it is suggested that this behavior induces a "physiological calming effect" (Laister et al., 2011) and helps resolve conflicts (Val-Laillet et al., 2009). Licking behavior in cows reduces the heart rate of the receiver (Laister et al., 2011) and was found to be directed more toward lame cows compared with nonlame cows kept in the same stall (Galindo and Broom, 2002). These findings suggest that licking behavior may have a role in alleviating discomfort (Galindo and Broom, 2002). In cases where grouping is necessary, an intermediate solution could be to regroup cows in the company of familiar conspecifics to promote such affiliative interactions (Bøe and Færevik, 2003). Heifers that are introduced to a herd with a familiar conspecific (i.e., in pairs) face significantly fewer agonistic interactions compared with singly introduced heifers $\left(7.19 \mathrm{~h}^{-1}\right.$ vs. $3.79 \mathrm{~h}^{-1}$; Neisen et al., 2009) and integrate faster into the herd (Gygax et al., 2009). Heifers that are introduced to a new group in pairs show greater resemblance between their time budget and the time budget of other cows in the herd (e.g., time spent in the lying areas and feeding areas), compared with heifers that were introduced singly (Gygax et al., 2009; for increased lying times of heifers integrated in pairs compared with singly introduced heifers, see also O'Connell et al., 2008).

\section{Contact with Humans}

When kept indoors, cows rely on humans for almost every aspect of their lives. The interaction with humans is at times, inevitable, and varies between farms according to management policy, the size of the herd, and the level of automation on the farm. Daily interaction with humans has a significant effect on cows' behavior and productivity (Hemsworth, 2003). Humans can evoke fear in animals by virtue of their relative size, and their propensity for quick or unpredictable movements (Rushen et al., 1999). For example, the use of negative interactions by stock people (i.e., slaps, pushes, or hits with the hand or an object such as a plastic pipe) are negatively correlated with milk, protein, and fat yields, as well as with increased flight distance of cows (i.e., the percentage of cows approaching within $1 \mathrm{~m}$ of an experimenter in a standard test; Hemsworth et al., 2000). However, engaging intentionally in negative handling is not essential for a cow to experience a negative interaction with a human; several routine husbandry procedures practiced in dairy farms are intrusive by nature and can be aversive to cows, causing pain and stress (Pilz et al., 2012). For example, artificial impregnation of cows involves a series of intrusive procedures, which starts with the artificial insemination itself (i.e., including both rectal and vaginal intrusions) and continues with routine pregnancy examinations that involve rectal examination. Following an aversive treatment, dairy cows and calves learn to avoid the specific handler and place associated with the aversive experience (learned aversion; de Passillé et al., 1996; Rushen et al., 1998; Taylor and Davis, 1998). By practicing positive handling from an early age, farmers can both help their animals to reduce stress responses during aversive experiences (in the case of AI, positive interactions with stockpersons were found to be positively correlated with conception rates; Hemsworth et al., 2000) and induce positive affective states promoting positive welfare in the farm (Ellingsen et al., 2014; Proctor and Carder, 2014, 2015a,b).

Calves. In calves, positive handling during the first 4 wk of life (e.g., moving slowly and calmly around in the pen, speaking in a quiet and calm voice and encouraging interactions including pats and scratches) affects approach behavior toward familiar handlers, compared with negative handling (e.g., fast movements, speaking with a harsh voice and creating noise with different tools, such as a plastic bottle with rattling stones in it; Schütz et al., 2012). However, the impact of handling quality at an early age may be overshadowed by the amount of human contact at a later stage (after 3 mo; Schütz et al., 2012). When test calves (handled negatively and positively) were compared with a control group reared routinely on-farm (i.e., without any particular handling treatment), the latter showed greater avoidance behavior than both positively and negatively handled calves, demonstrating the importance of both quality and quantity of handling. In a more recent study, gentle interactions on group-housed dairy calves during the first $14 \mathrm{~d}$ of life were associated with smaller avoidance distances from a familiar person before and after weaning (i.e., $86.2 \pm 5.1 \mathrm{~d}$ old), and with higher average daily gain (up to $7 \%$, depending on milk provision, Lürzel et al., 2015). In beef cattle, gentle interactions (i.e., $120 \mathrm{~min}$ of touching over $6 \mathrm{~d}$ within 4 wk of life) were associated with less fearful behavior 
toward humans (i.e., smaller avoidance distances) and less stress-related behavior at the abattoir at the age of 10 mo (i.e., less avoidance behavior in the stunning box and a tendency for lower cortisol concentrations in the blood taken during exsanguination, Probst et al., 2012). Positive handling is also associated with a more positive mood, as assessed by qualitative behavior assessment (QBA; Ellingsen et al., 2014). In their study, Ellingsen et al. (2014) characterized the behavior of stockpersons and portrayed the body language of the dairy calves that were under their care. Calves handled patiently, petted, and talked to calmly were rated by respondents to be more "friendly" and "content." In contrast, stockpersons with a nervous handling style or who were dominating and aggressive had calves that were perceived as in a more negative mood (Ellingsen et al., 2014). However, the extent to which these QBA labels reflect real underlying mood states needs to be validated using more direct measurements of animal behavior and physiological state (e.g., Mendl et al., 2010). The effect of brushing calves by humans will be reviewed under sensory enrichment.

Cows. In cows, a high percentage of positive interactions (talking quietly, petting, and touching) and a low percentage of negative interactions (forceful use of stick or hand, shouting, and impatient talk) are associated with reduced avoidance of handlers in the milking parlor (Waiblinger et al., 2002). Waiblinger et al. (2004) found that the stress response to an aversive veterinary procedure could be reduced by positive handling before and gentle interactions during the procedure. In that study, positive handling included feeding cows a small amount of concentrate out of the hand, stroking them at the neck and head as long as they accepted it, and speaking to them in a soothing way for several minutes during $10 \mathrm{~d}$ distributed over a 4 -wk period. Gentle interactions applied during an aversive veterinary procedure consisted of stroking the cows at the neck and head and speaking to them in a soothing way. The authors found that cows previously handled in a positive way had a lower heart rate and kicked less when isolated for the procedure. In addition, cows that were calmed down during the procedure itself (i.e., gentle interaction) expressed less restless behavior (e.g., head shaking and tail flicking). The success of "calming down" the animals, however, differed between handlers (Waiblinger et al., 2004; for additional evidence of the effects of positive and negative handling, see Breuer et al., 2000; Hemsworth et al., 2000; Lensink et al., 2001; Rushen et al., 2001; Waiblinger et al., 2006; but see also Pajor et al., 2003 and Stewart et al., 2013 for limited or no effect of previous handling). Brushing by humans can also lower stress levels in times of isolation and will be discussed later under tactile enrichment.

\section{Occupational Enrichment}

Occupational enrichment encompasses both enrichment that encourages exercise and psychological (also referred to as cognitive) enrichment (e.g., devices that provide animals with control or opportunities to use their cognitive abilities; Bloomsmith et al., 1991).

\section{Enrichment that Encourages Exercise}

Calves. During the early stages of life, calves are raised alone, in pairs, or in groups. The space allowance for each calf varies between rearing systems (and stocking density) and has a direct effect on their ability to engage in voluntary physical training (Jensen et al., 1998). Physical training of animals can be achieved through play behavior, which can be directed at a conspecific or object and conducted alone or in company (Held and Spinka, 2011). In calves, play behavior was studied mainly in rearing conditions that allowed very limited voluntary movement (i.e., confinement). The motivation to perform locomotor play (i.e., galloping, bucking, and kicking, which involves no interaction between individuals) and trotting was shown to increase with the length of confinement (Jensen, 2001), suggesting that play is a behavioral need. A reduction in play behavior in young mammals has been proposed as a reliable indicator of the transition from positive to poor welfare (Held and Spinka, 2011). Indeed, play behavior in calves is shown to decrease when food provision drops (Duve et al., 2012) or when calves are subjected to painful procedures (e.g., hot-iron disbudding, Mintline et al., 2013). Improving the welfare of calves by rearing them in groups is associated with a higher rate of play behavior (Jensen et al., 1998). In a recent study, Valníčková et al. (2015) assessed the effect of social companionship (single vs. group housing) on play behavior. In that study, housing calves in groups was associated with more spontaneous play behavior in the pen compared with housing calves individually. In contrast, in an open-field test and during a social test (i.e., encounter with an unfamiliar conspecific), individually housed calves were more playful compared with group-housed calves (Valníčková et al., 2015). The lower levels of spontaneous play and the higher rebound effect during the open field test and during the social test (i.e., when calves were exposed to a larger space without or with companion) was suggested as indicating deprived natural levels of play behavior in individually housed calves (Valníčková et al., 2015). Although the occurrence of play behavior is generally low, its applicability as a measure of welfare in combination with other indicators is worth investigating further. Additional methods for encouraging exercise (i.e., via 
play behavior) will be further addressed under physical enrichment.

Cows. The motivation of cows to engage in physical activity (i.e., walk, trot, gallop, and jump) has mainly been studied in individuals kept in tiestall barns. Despite increasing criticism, tiestalls are still used throughout the world, with over $70 \%$ of dairy farms in Canada (Canadian Dairy Information Centre, 2014), $38 \%$ in the United States, $69 \%$ in Finland, and $78 \%$ in Switzerland (Barkema et al., 2015) tethering their cows. In the European Union, 20\% (lowland) and 80\% (upland) of cows are tethered at least during the winter (Veissier et al., 2008). Cows, similarly to calves, show increasing motivation to engage in physical activity as a function of the time they spend in confinement (i.e., tied up; Loberg et al., 2004; Veissier et al., 2008). Daily access to an exercise area (e.g., indoor exercise area, outdoor paddock, or preferably pasture) has been shown to revert locomotor activity of tied cows to levels observed in loose-housed cows (Veissier et al., 2008) and provides them with more opportunities to engage in social interactions, explore their environment and groom hard-to-reach hindquarters (Krohn, 1994). In Hérens cows (a Swiss breed that is highly motivated to engage in dominance interactions), daily access to an exercise yard was associated with lower frequency of agonistic interactions compared with access every $3 \mathrm{~d}$ or more (Castro et al., 2011). Likewise, Loberg et al. (2004) found lower levels of aggressive behaviors (i.e., threatening and pushing) in tied cows that had access to an exercise yard once a day compared with once a week. Engagement in exercise is also associated with positive effects on claw conformation (Loberg et al., 2004) and reduced incidence of lameness (Regula et al., 2004) and mastitis (Popescu et al., 2013). In farms where tethering is still practiced, daily exercise of more than $1 \mathrm{~h}$ is recommended as a measure to fulfill, at least to some extent, the motivation of cows to engage in movement (Veissier et al., 2008). For minimizing hock lesions, at least $50 \mathrm{~h}$ per month are recommended (i.e., preferably on pasture to allow the cows to lie down comfortably, Keil et al., 2006). In the latter study, the duration of each exercise period seemed to be particularly important, as increased frequency alone was not found to be beneficial. To our knowledge, the contribution of additional daily exercise to the welfare of cows kept solely in freestall systems (i.e., which can be crowded, with high traffic areas, and slippery walking surfaces that are very difficult to keep dry) has not yet been studied, and its practicality for high-yielding dairy cows and for calves should be considered separately.

\section{Cognitive Enrichment}

Recent studies have shown that farm animals are capable of more complex cognitive and emotional responses than previously thought (Broom, 2010). Yet, farm animal housing generally offers less stimulation and fewer opportunities for animals to use their cognitive abilities than those available in the wild (Langbein et al., 2009). Providing animals with more opportunity to use their cognitive abilities has been suggested to be an important component of animal wellbeing (Carlstead and Shepherdson, 2000); however, this key assumption still requires additional supporting evidence. Cognitive enrichment can give animals control over aspects of their environment and can lead to positive affective states. The majority of empirical work on the effects of providing animals with control over their environment has investigated control over punishment rather than reward (Sambrook and Buchanan-Smith, 1997). However, in recent years, there has been increasing evidence suggesting that the control of positive situations, such as situations that involve anticipation of consummatory reward, improves welfare (Bassett and BuchananSmith, 2007; Manteuffel et al., 2009).

Manteuffel et al. (2009) suggested that cognitive enrichment of group-housed animals on commercial farms could be achieved using self-controlled operant learning tasks and adapting the degree of challenge to the cognitive abilities of each species. The initial stress and frustration that may arise when a challenge is presented to the animal is thought to be an important feature in the process of cognitive enrichment, as long as the animals possess the skills and resources to effectively solve the problems that they face (Meehan and Mench, 2007). Habituation and "over-experience," however, should be prevented by changing, to some extent, the conditioned discriminatory stimuli or by adding a further conditioned behavior (e.g., variable or fixed ratio lever pressing) to the initial one. In recent years, an increasing number of studies have explored, both directly and indirectly, the cognitive abilities of cattle (e.g., face perception and recognition, Coulon et al., 2011; spatial memory and decision making, Bailey et al., 1989a,b; operant conditioning and reversal learning, Wredle et al., 2006; Wechsler and Lea, 2007; Vaughan et al., 2014; Webb et al., 2014; reversal learning in calves, Gaillard et al., 2014). Nevertheless, to our knowledge, only Hagen and Broom (2004) specifically explored the effect of cognitive enrichment on cattle behavior. In this study, heifers were divided into an experimental group, where heifers were conditioned to press an operant panel to open a gate and gain access to a food reward, and a 
control group, where the gate opened automatically after a delay equal to their matched experimental group partner's latency to open it. Heifers that learned the operant task displayed evidence of greater "excitement" (i.e., higher heart rates and more vigorous movement) compared with control heifers, which received the same reward after spending the same amount of time in the pen. However, it is difficult to infer from this study the valence associated with the higher arousal of the experimental group, and whether these heifers indeed experienced enjoyment (contingent on understanding and gaining control over the task) or frustration (Spinka and Wemelsfelder, 2011).

When planning cognitive enrichment for a group of cows, individual differences arising from age or previous experience must be considered (Manteuffel et al., 2009). Indeed, individual differences can make an enrichment task solvable and rewarding for one group member but difficult and frustrating for another. Setting the complexity level of a task to the ability of the weakest animal in the group will allow all of the animals in the group to solve the task but may be too simple and easy for the majority of the group. A more promising solution that has not, to our knowledge, been tested yet in farm animals, would be to adjust the complexity level of the task to each member of the group. A system based on machine learning algorithms could adjust itself to the (changing) lifetime abilities of each individual. This kind of knowledge could be added to the individualized data that is already being collected in an increasing number of dairy farms around the world (e.g., daily milk yield, daily activity, or rumination time) and give the farmers a more detailed image of each individual animal kept in the group.

\section{Physical Enrichment}

The complex cognitive abilities of cows should also be considered when designing housing and husbandry systems (Broom, 2010). Physical enrichment includes altering the size or complexity of the animal's enclosure or adding accessories to the enclosure such as objects, substrate, or permanent structures (Bloomsmith et al., 1991).

Calves. Providing animals with access to alternate enclosures (i.e., by dividing space into different functional areas) was suggested to increase opportunities for exploration and patrolling, as well as for camouflage and hiding (Newberry, 1995). Dividing the space within an enclosure may also be beneficial for decreasing antagonistic interactions between calves. Ninomiya and Sato (2009) compared the rate of agonistic encounters (e.g., head butting, chasing, escaping) between Japa- nese Black calves kept in an enriched pen divided by a wooden wall with the rate of agonistic encounters between calves kept in a control, not divided pen. Dividing the space in the pen resulted in lower motivation of stronger calves to chase the weaker ones, possibly by preventing eye contact between the animals and forcing them to pass through narrow gaps to come into contact with each other (Ninomiya and Sato, 2009). However, because the authors did not control for additional factors, such as the effect of the brush and wood log that were also placed in the enriched cage, the role of the wooden wall in decreasing agonistic behavior cannot be clearly demonstrated.

Alternating the physical environment of calves, in addition to reducing agonistic behaviors, can be used to encourage play and related exercise. Providing calves with increased space allowance (i.e., $1.8 \times 3.0 \mathrm{~m}$ compared with $0.9 \times 1.5 \mathrm{~m})$ is associated with higher levels of play behavior (Jensen et al., 2015a). Adding additional stimuli to the enclosure (i.e., provision of fresh bedding) also appears to stimulate the occurrence of this behavior (Jensen et al., 1998; see also Schütz et al., 2012). Jensen et al. (1998) reported that provision of straw in connection with morning feeding (i.e., when fresh straw was supplied every day after milk feeding) stimulated the largest daily peak in play behavior. Playing with straw was reported by the authors to resemble ground play as opposed to object play. Ground play consists of the calf rubbing its head and neck against the ground while kneeling down (Schloeth, 1961). However, because fresh straw was always supplied following morning feeding in Jensen et al. (1998), its effect on play behavior cannot be fully evaluated, as it is not possible to separate time of day effects from the effect of straw. Encouraging play behavior in calves by the use of other substrates or external objects (e.g., cow brushes or balls hanging at a height of $1.3 \mathrm{~m}$ ) may prove beneficial when social isolation is mandatory (e.g., quarantine, Bulens et al., 2014).

Cows. In zero-grazing systems, cowsheds are usually designed to provide constant visual and physical contact between conspecifics. Allowing cows to maintain contact with each other corresponds, at least to some extent, to their natural need to live in a group. However, in the wild, cows also have the possibility to isolate themselves from the group when they need to, such as the time around calving (Lidfors et al., 1994). The need to isolate oneself from the group seems to be important also for high-yielding cows used today in the industry. Proudfoot et al. (2014a) showed that, when given the opportunity, dairy cows housed in individual maternity pens preferentially used a secluded area to calve. Cows began using the secluded area more than usual during 
the hour before calving and continued to use it more for the hour after calving. The need to isolate oneself from the group was also documented during times of illness. Proudfoot et al. (2014b) found that cows with high rectal temperature after calving and signs of an infectious disease (mastitis, metritis, pneumonia, or some combinations of these diseases) spent more time in the secluded area compared with healthy cows. Building secluded areas inside the cowshed thus seems to provide cows with the opportunity to express, to some extent, their natural need to isolate themselves from the group. Cows should have free access to these secluded areas, as the need for isolation at times of morbidity is not shared by all group members and not for all morbidity cases (e.g., lame cows, Jensen et al., 2015b). Secluded areas that cows can access freely can be introduced in both loose-housing systems (e.g., by installing a "movable" fence that can be folded when the soil needs to be cultivated) and in freestall systems (e.g., by installing dense nets that provide a visual barrier but still allow airflow). Monitoring the occupation of such areas (i.e., in calving pens, hospital pens, and free-access secluded pens) may prove to be beneficial for farmers too, as they could acquire an additional indicator of the wellbeing of their cows and their proximity (i.e., in time) to calving. The need to minimize contact with the group can also appear in low-ranking dairy cows at times of high aggression in the shed (feeding time; Haskell et al., 2013). For example, providing access to a loafing area allows low-ranking cows to avoid dominant animals (Haskell et al., 2013). The extent to which summer yards or exercise yards (i.e., adjacent to the cowshed that allow animals to "sunbathe") can further contribute to enrich the physical environment of cows should be explored in future studies.

Enriching the lying area of cows by providing them with a comfortable lying surface (i.e., soft, nonabrasive, clean, and dry) was also suggested to be an important factor in enhancing cows' comfort and welfare (Tuyttens, 2005; Fregonesi et al., 2007). Bedding materials can vary from organic or mostly organic materials (e.g., straw or sawdust) to inorganic (e.g., sand) or synthetic materials (e.g., mats made of rubber combined with polypropylene and nylon). The preferences of cows can strongly differ depending on the type of bedding (Norring et al., 2008), quantity of bedding (Jensen et al., 1988), quality of bedding (i.e., whether the lying surface is dry or wet; Fregonesi et al., 2007), the season (summer and winter, Manninen et al., 2002), and previous experience (Tucker et al., 2003). However, their preference for some bedding materials may not necessarily fit the long-term benefit of the animal. For example, bedding with straw, compared with sand, was associated with increased lying time (straw $749 \pm 16$ vs. sand
$678 \pm 19$ min per day). However, it was also associated with more severe hock lesions and less improvement in overall foot health (Norring et al., 2008). The costs of bedding materials can be high in some countries and lying mats can therefore be used as a measure to reduce the cost of bedding by placing small quantities of bedding materials on them (Norring et al., 2010; for further information on bedding, see review by Tuyttens, 2005). Other measures that can enrich the physical world of cows, such as placing cow brushes inside the cowshed, will be addressed in the sensory enrichment section.

\section{Sensory Enrichment}

Sensory enrichment is defined as stimulation designed to trigger one or more of an animal's senses; Wells, 2009). The stimulation can be achieved through visual (e.g., television), auditory (e.g., music, vocalizations), or other modalities (e.g., olfactory, tactile, taste; Bloomsmith et al., 1991). As very few studies have been conducted in each subfield of sensory enrichment, we shall discuss both age groups (i.e., calves and cows) together.

\section{Auditory Enrichment}

When considering the use of auditory enrichment, the excellent hearing of cows, compared with humans, should be taken into account. The hearing range of cattle lies between $23 \mathrm{~Hz}$ and $35 \mathrm{kHz}$, nearly double the frequency range of humans (Heffner and Heffner, 1983). Exposing cattle to high-pitch sounds is thought to damage their hearing and affect feeding behavior (Johns et al., 2015). The environment on commercial dairy farms can be loud and noisy: the sound of metal gates opening and closing, tractors carrying TMR or straw, and vacuum-operated milking machinery are only some of the noises that cows are exposed to frequently. Waynert et al. (1999) reported that beef heifers exposed to the noise of clanging metal and humans shouting had higher heart rates and activity than cattle in a quieter environment. Similarly, noise recorded from a commercial milking facility induced fear in dairy heifers and, when given the opportunity, heifers learned to avoid these noises (Arnold et al., 2008). Although the results of the latter study cannot be generalized to all kinds of milking machinery and may depend on farm management, they align with the argument that an overall reduction of ambient noise, rather than additional acoustic stimulation, might be more important for the animals themselves (Wells, 2009). In accordance with this view, Newberry (1995) emphasized that adding auditory stimuli to an environment that is already noisy may cause more harm than good, especially if 
the animals have no control over the sound (i.e., such as the ability to move to a quieter location or to switch off the sound).

On farms, auditory stimuli are used for a variety of tasks, from improving cow traffic in automatic milking systems (Uetake et al., 1997) to training cattle to approach a food source (Wredle et al., 2004). In most cases, the association between the auditory stimulus and cow behavior is established using classic or operant conditioning. In a recent study, Kıyıc1 et al. (2013) used music as a measure to reduce cows' stress levels during milking. Cows that were played classical music (during the milking period, for a period of $28 \mathrm{wk}$ ), compared with no music, had higher milk let-down speed $(6.27 \pm$ $0.12 \mathrm{~min}$ vs. $6.68 \pm 0.13 \mathrm{~min}$, respectively). However, because those authors did not control for the effect of classical music on the workers and its possible effect on their handling of cows, and did not measure stress levels in the cows, the association between classical music and stress levels cannot be clearly determined. If, indeed, playing classical music in the milking parlor has an indirect effect on the welfare of cows (i.e., by affecting the milkers themselves), an intermediate solution that would reduce ambient noise for cows while enabling farmers to hear music would be the use of earphones.

In addition to classical music, some studies tested for the effect of more "natural" auditory stimuli, such as playbacks of calf vocalizations, on increased milk yield. Pollock and Hurnik (1978) exposed cows in the milking parlor to playbacks of calf calls. The broadcast of calls started just as the cows entered the milking parlor and ceased when the last teat cup had been placed on the last cow. Milk let-down during the first 2 min of milking was higher in the treatment group compared with the control group, which was not exposed to calls (average production of 16 cows $=81.1 \pm 0.4 \mathrm{~kg}$ vs. $79.7 \pm 0.5$ $\mathrm{kg}$, respectively). In a more recent study, McCowan et al. (2002) reported an increase of 1 to $2 \%$ in milk yield during the second milking session following playbacks of calf calls. Although the results of these 2 studies present a positive association between exposure to playbacks of calf vocalizations and milk yield and release, their effect on the emotional state of the cow was not assessed (McCowan et al., 2002). It has been suggested that, as in most other mammals (Manteuffel et al., 2004; Briefer, 2012), vocalizations in cattle may signal the physiological and emotional state of the calling animal (Thomas et al., 2001; Marchant-Forde et al., 2002; Ikeda and Ishii, 2008). Indeed, previous studies have shown that calves vocalize more before feeding time and that calves fed by conventional management (i.e., twice daily for a total of $5 \mathrm{~L}$ during $24 \mathrm{~h}$ ) produce more calls compared with calves fed every $4 \mathrm{~h}$ with $8 \mathrm{~L}$ of milk per day (31.4 \pm 7.0 vs. $5.0 \pm 3.4$ respectively; Marchant-Forde et al., 2002). The calls used in Pollock and Hurnik (1978) and McCowan et al. (2002) were produced by calves that were either deprived of food (for $8.5 \mathrm{~h}$; Pollock and Hurnik, 1978) or before milk feeding (McCowan et al., 2002). Marchant-Forde et al. (2002) found that cows that were played recordings of calves (i.e., produced in similar conditions - in a commercial farm, 1 wk of age, before feeding) compared with white noise had greater heart rate response, increased head and ear movements, were oriented more toward the speaker, and spent less time eating. Because calf-call playbacks were played to the cows throughout the milking session in McCowan et al. (2002) and during part of it in Pollock and Hurnik (1978), a negative emotional reaction in the cows might have been triggered through, possibly, emotional contagion. The appropriateness of using this procedure as a measure to increase milk yield, and its possible influence on the public opinion, should be weighted into the equation when considering its use.

\section{Visual Enrichment}

The visual system of cattle is very sensitive to motion and contrasts of light and dark (Grandin, 2000). The lateral eye position enables cattle to constantly scan the horizon (up to $330^{\circ}$ ) for predators and facilitates other activities, such as sexual (mounting) behavior (Grandin, 2000; Tucker, 2009). Visual enrichment, as opposed to auditory and olfactory enrichment, can be simply avoided by the animals when found to be aversive (i.e., by closing their eyelid or diverting their gaze away) and consequently controlled (Wells, 2009). However, to the best of our knowledge, very little work has been carried out on the effect of visual enrichment on cattle. Haskell et al. (2013) found no significant effect of access to a view of surrounding fields and farm tracks on the motivation of cows to occupy a loafing area. Those authors' interpretation was that a view of the surroundings has little motivational value for cows. However, because the effect of visual access to the surroundings was not assessed during feeding time (i.e., food was placed inside the cowshed), when lying down (i.e., loafing area had concrete flooring, which is less favored by cows) or during the evening and night (i.e., observations in this study were conducted only during daylight hours), further investigation on this potential enrichment is needed. An additional factor that should be controlled for when assessing the effect of visual surroundings on dairy cattle is the confounding effect of previous experience (discussed above under physical and cognitive enrichment, Tucker et al., 2003; Manteuffel et al., 2009). Piller et al. (1999) studied the effect of mirror-image exposure on heart rate and 
movement of isolated heifers. The presence of mirrors was associated with reduced heart rate and movement, and had a greater calming effect when mirrors were placed directly in front of the animal compared with a reflected side view. In accordance with these results, Coulon et al. (2011) found that heifers were more attracted to images of familiar conspecifics (i.e., chosen first, explored more, and given more attention) compared with images of unfamiliar conspecifics. If images of conspecifics are indeed treated as representations of real individuals, they might prove to be beneficial for lowering stress levels during husbandry or medical procedures that require isolation. In a study measuring salivary cortisol and chromogranin A concentrations from 3 Japanese Black cows, a picture of a companion, compared with a blank picture, tended to decrease, albeit not significantly, the stress response measured $30 \mathrm{~min}$ after the start of the isolation. However, $2 \mathrm{~h}$ later, the opposite effect was observed for salivary cortisol levels (Ninomiya and Sato, 2011). One possible explanation for the time-limited effect of presenting a picture of a companion on lowering stress levels is that frustration might build over time because of the inability to eventually engage in contact with the conspecifics (Wells, 2009). More research is needed to gain a better understanding of the short- and long-term beneficial effects of this tool in lowering stress. It is important to point out that reducing stress responses in cattle can also be achieved by eliminating, rather than enriching, visual input. Mitchell et al. (2004) found that preventing beef cattle from seeing by blindfolding them reduced the amount of struggle and tended to lower the heart rate during restraint. We encourage research aimed at a better understanding of the "calming effect" induced by blindfolding and a systematic comparison between these 2 approaches (i.e., mirror vs. blindfolding).

\section{Olfactory Enrichment}

Cattle, compared with humans, have a very sensitive sense of smell. Using their vomeronasal organ, cattle can detect pheromones indicating the reproductive state of their conspecifics or their stress state (via their urine; Terlouw et al., 1998). To our knowledge, only one study has assessed the suitability of olfactory enrichment in cattle. Wilson et al. (2002) compared 2 tactile enrichment devices (e.g., a scratching/rubbing walkway and a movable scratching/rubbing device), 2 olfactory enriching devices (e.g., a milk-scent releasing device and a lavender-scent releasing device), and a control, nonscented device. Their results showed that tactile enriching devices were used for a longer duration, more frequently, and by a higher percentage of cows compared with the scent devices. Moreover, the initial preference that cows displayed toward the milkand lavender-scent devices over the nonscented control device decreased over the course of the experiment. The authors concluded that scratching/rubbing devices are better candidates for environmental enrichment than scent devices, as the interest that cows display toward them does not fade over time. A different approach that holds higher biological relevance and that, to our knowledge, has not been tested yet, is to enrich the scent of cows' food ration, either with artificial or natural smell. One possible constraint associated with this idea is the reluctance of ruminants to eat novel food (known as food neophobia; Launchbaugh, 1995), and the possible association of the new smells with new tastes. We will further discuss this limitation in the nutritional enrichment section.

\section{Tactile Enrichment}

On pasture, cattle use trees and other inanimate objects to groom themselves. The use of trees for rubbing seems to originate from a different need than grooming behavior. When trees are available, cattle will use them for scratching different body regions, without spending less time self-grooming and allogrooming than when trees are absent (Kohari et al., 2007). Inside the dairy farm, lacking any trees, dairy cows rub their bodies and mainly their heads and necks on metal gates, fences, and water troughs (DeVries et al., 2007). A useful tactile enrichment device that can be placed on the farm and ease grooming behavior of cows is an automated brush. Automatic brushes allow cattle to groom themselves, particularly in body regions that they find hard to reach otherwise (DeVries et al., 2007) and were shown to be preferred over fixed brushes (Gutmann 2010). In addition to providing the cows with an opportunity to engage in scratching/rubbing behavior, the brushes are also associated with better body cleanliness and in some situations, improved milk yield (second lactation; Schukken and Young, 2009). Once a brush is installed on the farm, calves, lactating dairy cows, dry cows, and breeding bulls (both young and mature) will use it daily (Georg and Totschek, 2001; DeVries et al., 2007; Georg et al., 2007; Hoyer, 2013; Mandel et al., 2013; Newby et al., 2013). The frequency of brush usage varies between cows and housing systems and was found to be considerably higher (4- to 7-fold) in studies where cows and bulls were housed individually (Hoyer, 2013; Newby et al., 2013), compared with studies where one brush was present for a group of cows (Georg and Totschek, 2001; DeVries et al., 2007; Georg et al., 2007; Mandel et al., 2013). The high usage 
rates by individually housed cows can be attributed to reduced competition over this resource (Val-Laillet et al., 2008), boredom (Hoyer, 2013), or simply the lack of allogrooming possibilities. Another factor that plays an important role in brush utilization is the location of the brush and its distance from the food bunk (Mandel et al., 2013). In addition to its hedonistic character and high utilization rates, brush usage can serve as an interesting tool to measure and identify stress and morbidity in dairy cows (Mandel et al., 2013). Indeed, in the latter paper, we found reduced brush usage under heat load and following intrusive medical procedures (i.e., stress; Mandel et al., 2013). In accordance with this idea, a recent study showed that brush usage is also reduced among steers infected with bovine respiratory disease (BRD) on the day of peak illness (i.e., morbidity; Toaff-Rosenstein et al., 2014).

The need of cows to engage in scratching or rubbing behavior can also be achieved by brushing them manually. In a recent study, Westerath et al. (2014) examined whether calves judge human brushing as positive. The majority of calves faced with a preference test preferred a compartment with a human that brushed the animals over an empty compartment. The authors mentioned that all calves "leaned against the brush" and "stretched the neck while being brushed," possibly indicating some kind of perceived pleasure when being brushed. However, the authors emphasize the need to habituate animals to being brushed, in order for the positive effect of brushing to exceed the fear of novelty or the fear of a contact with humans (as opposed to very rapid adaptation of cows to automated brushes; DeVries et al., 2007). Accordingly, Westerath et al. (2014) also mention that some of the animals used in their study never habituated to being brushed by the experimenter, implying that this action is not perceived to be positive by all individuals. Hanging manila ropes (i.e., fiber ropes originally used for pathogen sampling) in the yard may also serve as a tactile enrichment device (Stanford et al., 2009). Following a short adaptation period, cattle will lick and nibble the rope on a daily basis (Stanford et al., 2009). Calves and heifers interact more with the rope than mature cows (Stanford et al., 2005, 2009). However, to our knowledge, the nature of the motivation to engage in this behavior was not investigated, and its origin should be assessed to control for nutritional deficits or stereotypic origin.

\section{Nutritional Enrichment}

Nutritional enrichment can involve either presenting varied or novel food types or changing the method of food delivery (Bloomsmith et al., 1991).
Calves. Calves start to suckle milk from their dam within hours of birth (domestic settings: Edwards and Broom, 1982; nondomestic settings: Tucker, 2009). The motivation to suckle at this age is very high, and the frequency of milk intake in dairy calves ranges between 8 and 12 times a day (dairy calves; Jensen, 2003). Calves kept with their dam can suckle at will and tend to have frequent suckling bouts during which they ingest small amounts of milk at a time (Kalber and Barth, 2014). In the following weeks, the frequency of milk intake will gradually decrease to 3 to 4 times a day (Jensen, 2003), allowing a plant-based diet to slowly build up. Natural weaning occurs between 6 and 12 mo (Newberry and Swanson, 2008). Allowing calves to suckle directly from the teats of their dam or foster cow (i.e., either in a full- or restricted-contact dam-rearing system) has been associated with higher growth rates and reduced cross-sucking behavior (Roth et al., 2009). However, the higher growth rate associated with dam rearing could be confounded by a higher milk intake (of natural milk) compared with calves provided with milk replacer (Kalber and Barth, 2014).

In most intensive farming systems, calves are raised separately from their dam and milk is typically provided via a teat feeder or in a bucket. When fed from a bucket, calves consume a large amount of milk in a very short time (i.e., $2.5 \mathrm{~L}$ in about $1 \mathrm{~min}$, compared with 8 to $12 \mathrm{~min}$ for an average suckling bout from the dam's udder; Loberg and Lidfors, 2001). Feeding calves from an open bucket (i.e., without a nipple) is cheap and easy to maintain but does not provide calves with the ability to perform suckling behavior. Preventing calves from performing suckling behavior may result in its redirection toward pen objects or peers (i.e., crosssucking). Although the origin of cross-sucking behavior is thought to be influenced by multiple factors, such as milk allowance and age of weaning, recent findings show that cross-sucking may reflect individual differences or be the result of habit formation (de Passillé et al., 2011).

The traditional method for treating cross-suckling behavior is to install a pronged nose-ring or halter on the nose of the suckling calf. Spikes attached to the nose ring or halter provoke avoidance behavior among group members, and limit their ability to suckle each other. The method was criticized for targeting the signs rather than the cause (Keil et al., 2000). An alternative treatment that deals with the cause itself and gives calves the opportunity to perform suckling behavior is to place a rubber nipple in the pen. de Passillé and Caza (1997) showed that the occurrence of cross-suckling behavior is reduced by more than $75 \%$ when calves are presented with dry rubber nipples following milk 
intake from a bucket. However, although the rate of cross-suckling was reduced using this method, it still involves the performance of a functionless behavior (i.e., sucking a dry rubber teat), which may be referred to as stereotypic (de Passillé et al., 2011). A more promising solution is to provide calves with nutritive feeding nipples (i.e., where milk is being provided through the rubber nipple), which reduces both cross-suckling behavior (de Passillé, 2001; Jensen and Weary, 2013) and the time spent in nonnutritive suckling (i.e., when milk is finished and the nipples are dry; de Passillé et al., 2011). The nutritive rubber nipple can be connected to a bucket (i.e., teat-bucket) or to a feeder (i.e., teat-feeder) and used to provide calves with several milk meals a day. Because calves, when suckling from their mothers, tend to switch quarters once milk flow begins to decline (in contrast to piglets which use the same teat; Haley et al., 1998), placing shoulder barriers between feeding stations is encouraged to prevent competition between calves (Jensen et al., 2008). Enriching the environment of a teat-feeder by adding a postfeeding area with nonnutritive rubber teats and a net filled with a hay bale can further reduce cross-sucking behavior (Ude et al., 2011).

Cows. On pasture, dairy cows graze between 6 and $12 \mathrm{~h} / \mathrm{d}$, depending on nutrient availability, ingestion speed, and competition over food resources (Coffey et al., 1992). However, when cows are kept indoors, feeding time is reduced to $4 \mathrm{~h} / \mathrm{d}$ on average (Gomez and Cook, 2010). This change in feeding time can be explained, at least to some extent, by the highly predictable food location and the easily consumed form in which food is being dispensed in indoor conditions (e.g., fenceline feeding of TMR; Newberry, 1993; Gomez and Cook, 2010). This form of dispensing food is, however, associated with increased incidence of agonistic interactions, which is usually not the case on pasture, when the animals are spaced out from each other (Miller and Wood-Gush, 1991). Providing cows with a larger feeding space $(1.0 \mathrm{~m} / \mathrm{cow}$ compared with $0.5 \mathrm{~m})$ resulted in at least a $60 \%$ increase in space between animals and a $57 \%$ reduction in aggressive interactions while feeding (DeVries et al., 2004). This change was associated with increased feeding activity throughout the day, especially during the 90 min after providing fresh feed (an increase of 24\%). More importantly, the increase in feeding activity was particularly evident for subordinate cows. When it is not possible to provide extra feeding space per cow, placing feed barriers (i.e., headlocks) can serve as an intermediate solution that decreases displacements at the feeding bunk by more than 20\% (Endres et al., 2005).

Although keeping cows indoors seems to affect the "naturalness" of their feeding behavior (i.e., the extent to which a behavior resembles that performed in more extensive or natural environment), the functionality and adaptiveness of indoor feeding techniques should be emphasized (Newberry, 1995). The demand for high milk yield in intense dairy farming systems places high metabolic demand on dairy cows (Butler and Smith, 1989; Rauw et al., 1998; Oltenacu and Algers, 2005; Veerkamp et al., 2009). Providing cows with easier access to food (i.e., in the form of TMR) reduces the time they need to spend standing to feed, and may thus be adaptive in order for cows to cope with the energetic demand placed on them. However, the functionality and adaptiveness of this feeding method for heifers is not clear, as they do not share the same metabolic demands as lactating dairy cows, and are consequently left to occupy longer periods with a limited range of possible behavioral patterns. Providing part of the daily food ration through a food net (or a device that forces the animal to engage in food collection, such as pulling the hay from a bundle rather than just picking it up from the floor) may prolong the duration of feeding behavior and serve as a measure to increase the "naturalness" of calf feeding behavior. Providing essential resources (such as food) both in their regular form (i.e., feed bunks) and as a reward (i.e., food net), can enrich cows' feeding experience through contrafreeloading (i.e., where an animal will work for a reward in the presence of the same reward available freely; reviewed by Inglis et al., 1997) and may contribute to their welfare. We encourage further investigation of this idea as an enrichment method for heifers.

Offering animals a wider selection of food types was also suggested to be a potential source of enrichment (Newberry, 1995). Bioactive forages, for example, are offered to combat gastrointestinal parasites and serve as an alternative to anthelmintic drugs (Hutchings et al., 2003). However, when considering the practicality of this enrichment method, one should also take into account the effect of neophobia toward unfamiliar food (Westerath et al., 2014; although see Costa et al., 2014 for reduced neophobia in calves raised in complex social groups including both calves and cows). Familiarizing the cows with varying types of food (some of which is regarded to be more rewarding and some less; for example, concentrate in calves; Westerath et al., 2014) may prove to be beneficial in decreasing neophobia, but could affect bacterial diversity in the rumen, which plays a major role in the productivity and health of cows (Callaway et al., 2010). In addition, food that is considered to be more rewarding (e.g., concentrate in calves, Westerath et al., 2014) may increase competition and render the food accessible only to more dominant cows. In accordance with this idea, RiojaLang et al. (2009) showed that dairy cows trade off 
food quality with proximity to a dominant individual in Y-maze choice tests. Therefore, enriching the food of farm animals (using familiar food that is perceived to be more rewarding by the animals) might prove to be more suitable in farms that dispense food individually (via individual recognition systems) or in farms that install proper barriers between feeding stations to avoid agonistic behaviors (Hetti Arachchige et al., 2014). A different approach that, to our knowledge, has not been tested yet is to use nutritional enrichment as a measure to detect lack of sufficient nutrients in the diet. Bell and Sly (1983) showed that the hedonic characteristics of nutritional enrichment such as salt-licks may be limited to nutrient-deficient cattle. However, this idea should be further examined.

\section{CONCLUSIONS}

Indoor housing of dairy cows and calves is associated with various challenges for the animals, such as the constraint to occupy long periods with a limited range of behavior patterns, as well as maintenance in abnormal social groups (Hughes and Duncan, 1988; Morgan and Tromborg, 2007). Here, we have reviewed environmental enrichment methods that are aimed at assisting cattle to cope better with stressors in their environment, prevent frustration, and increase the fulfillment of behavioral needs. As animal welfare is considered not only as the absence of stress and harm but also as the promotion of better affective conditions (Boissy et al., 2007), the implementation of cognitive enrichment that can lead to positive emotions was also discussed. Several of the basic behavioral requirements described here (e.g., social enrichment in the form of contact with conspecifics) are considered as minimal requirements for raising standards for gregarious animals, and in some countries are enshrined under legislative acts (e.g., European Union Council Directive 2008/119/EC, Article 3; European Union, 2008b). However, in many other countries, even these basic requirements are not met (Fraser et al., 2013). Enrichment methods aimed at fulfilling other important behavioral needs (e.g., providing cows with a secluded area to calve or feeding calves with milk through a nipple) have the potential to advance the welfare of dairy cows and calves but are not yet statutory. Finally, the contribution of enrichment methods that are less biologically relevant (reviewed here under olfactory and auditory enrichment; e.g., classical music, lavender smell) to the well-being of cattle is, however, less clear. Newberry (1995) argued that "enrichment attempts will fail if the environmental modifications have little functional significance to the animals, are not sufficiently focused to meet a specific goal, or are based on an incorrect hypothesis regard- ing the causation and mechanisms underlying a problem." Once these criteria are met, other factors, such as the accessibility of the enrichment device to cows from different hierarchical rankings (and competition over resources), as well as the difficulty of cleaning and disinfecting enclosures and other enrichment materials, should be taken into consideration when assessing the practicality of a specific enrichment device. The benefits of enriching the environment of dairy cows and calves, in terms of improving the physical and mental state of the animals and, in some cases, increased productivity, should be weighted in the expected costs of integrating these methods into commercial farms, and may consequently play an important part in increasing the motivation of farmers to adopt these methods. Several of the methods described here will, in time, be integrated into the minimum raising standards of cattle, whereas others will remain under the scope of enrichment and continue to pull the field of animal welfare forward, allowing us to deepen our understanding of farm animals and their needs inside the industry. As zero-grazing systems gain popularity around the world, more research will be needed to assess their impact on the well-being of the animals, and the development of enrichment methods that are better adapted to cows and calves housed indoors will be required.

\section{ACKNOWLEDGMENTS}

We thank E. Briefer (Institute of Agricultural Sciences, ETH Zürich, Zürich, Switzerland), M. L. Wenker (Animal Production Systems Group, Department of Animal Sciences, Wageningen University, Wageningen, the Netherlands), and three anonymous reviewers for helpful comments on the manuscript. R. M. is funded by the Universities Federation for Animal Welfare and by the Harry and Sylvia Hoffman Leadership and Responsibility Program at the Hebrew University, Israel.

\section{REFERENCES}

Algers, B., G. Bertoni, D. Broom, J. Hartung, L. Lidfors, J. Metz, L. Munksgaard, T.N. Pina, P. Oltenacu, J. Rehage, and J. Rushen. 2009. Scientific report on the effects of farming systems on dairy cow welfare and disease. Report of the Panel on Animal Health and Welfare (Question No EFSA-Q-2006-113). EFSA J. 1143:138. http://dx.doi.org/10.2903/j.efsa.2009.1143r.

Almeida, P. E., P. S. D. Weber, J. L. Burton, and A. J. Zanella. 2008. Depressed DHEA and increased sickness response behaviors in lame dairy cows with inflammatory foot lesions. Domest. Anim. Endocrinol. 34:89-99.

Arnold, N. A., K. T. Ng, E. C. Jongman, and P. H. Hemsworth. 2007. The behavioural and physiological responses of dairy heifers to tape-recorded milking facility noise with and without a pretreatment adaptation phase. Appl. Anim. Behav. Sci. 106:13-25.

Arnold, N. A., K. T. Ng, E. C. Jongman, and P. H. Hemsworth. 2008. Avoidance of tape-recorded milking facility noise by dairy heifers in a Y maze choice task. Appl. Anim. Behav. Sci. 109:201-210. 
Bach, A. 2012. Ruminant Nutrition Symposium: Optimizing performance of the offspring: Nourishing and managing the dam and postnatal calf for optimal lactation, reproduction, and immunity. J. Anim. Sci. 90:1835-1845.

Bailey, D. W., L. R. Rittenhouse, R. H. Hart, and R. W. Richards. 1989b. Characteristics of spatial memory in cattle. Appl. Anim. Behav. Sci. 23:331-340.

Bailey, D. W., L. R. Rittenhouse, R. H. Hart, D. M. Swift, and R. W. Richards. 1989a. Association of relative food availabilities and locations by cattle. J. Range Manage. 42:480-482.

Barkema, H. W., M. A. G. von Keyserlingk, J. P. Kastelic, T. J. G. M. Lam, C. Luby, J. P. Roy, S. J. LeBlanc, J. P. Keefe, and D. F. Kelton. 2015. Invited review: Changes in the dairy industry affecting dairy cattle health and welfare. J. Dairy Sci. 98:7426-7445. http://dx.doi.org/10.3168/jds.2015-9377.

Bassett, L., and H. M. Buchanan-Smith. 2007. Effects of predictability on the welfare of captive animals. Appl. Anim. Behav. Sci. 102:223-245.

Baumans, V., and P. L. P. Van Loo. 2013. How to improve housing conditions of laboratory animals: The possibilities of environmental refinement. Vet. J. 195:24-32.

Bell, F. R., and J. Sly. 1983. The olfactory detection of sodium and lithium salts by sodium-deficient cattle. Physiol. Behav. 31:307312

Bloomsmith, M. A., L. Y. Brent, and S. J. Schapiro. 1991. Guidelines for developing and managing an environmental enrichment program for nonhuman primates. Lab. Anim. Sci. 41:372-377.

Bøe, K. E., and G. Færevik. 2003. Grouping and social preferences in calves, heifers and cows. Appl. Anim. Behav. Sci. 80:175-190.

Boissy, A., G. Manteuffel, M. B. Jensen, R. O. Moe, B. Spruijt, L. J. Keeling, C. Winckler, B. Forkman, I. Dimitrov, J. Langbein, M. Bakken, I. Veissier, and A. Aubert. 2007. Assessment of positive emotions in animals to improve their welfare. Physiol. Behav. 92:375-397.

Borderas, T. F., A. M. de Passillé, and J. Rushen. 2008. Behavior of dairy calves after a low dose of bacterial endotoxin. J. Anim. Sci. 86:2920-2927.

Boyle, A. R., C. P. Ferris, and N. E. O'Connell. 2012. Are there benefits in introducing dairy heifers to the main dairy herd in the evening rather than the morning? J. Dairy Sci. 95:3650-3661.

Breuer, K., P. H. Hemsworth, J. L. Barnett, L. R. Matthews, and G. J. Coleman. 2000. Behavioural response to humans and the productivity of commercial dairy cows. Appl. Anim. Behav. Sci. 66:273-288.

Briefer, E. F. 2012. Vocal expression of emotions in mammals: Mechanisms of production and evidence. J. Zool. (Lond.) 288:1-20.

Broom, D. M. 2010. Cognitive ability and awareness in domestic animals and decisions about obligations to animals. Appl. Anim. Behav. Sci. 126:1-11.

Broom, D. M., and J. D. Leaver. 1978. Effects of group-rearing or partial isolation on later social behaviour of calves. Anim. Behav. 26:1255-1263.

Bulens, A., S. Van Beirendonck, J. Van Thielen, and B. Driessen. 2014. The effect of environmental enrichment on the behaviour of beef calves. Page 235 in Proc. 6th Int. Conf. Assessment of Animal Welfare at Farm and Group Level, Clermont-Ferrand, France. Wageningen Academic Publishers, Wageningen, the Netherlands.

Butler, W. R., and R. D. Smith. 1989. Interrelationships between energy balance and postpartum reproductive function in dairy cattle. J. Dairy Sci. 72:767-783.

Callaway, T. R., S. E. Dowd, T. S. Edrington, R. C. Anderson, N. Krueger, N. Bauer, P. J. Kononoff, and D. J. Nisbet. 2010. Evaluation of bacterial diversity in the rumen and feces of cattle fed different levels of dried distillers grains plus solubles using bacterial tag-encoded FLX amplicon pyrosequencing. J. Anim. Sci. 88:3977-3983

Canadian Dairy Information Centre. 2014. Dairy barns by type in Canada. Accessed Sept. 9, 2015. http://www.dairyinfo.gc.ca/ index_e.php?s1=dff-fcilands $2=$ farm-fermeands $3=$ db-el.

Carlstead, K. C., and D. J. Shepherdson. 2000. Alleviating stress in zoo animals with environmental enrichment. Pages 337-354 In The
Biology of Animal Stress: Basic Principles and Implications for Animal Welfare. G. P. Moberg and J. A. Mench, ed. CAB International Publishing, Wallingford, UK.

Castro, I. M., L. Gygax, B. Wechsler, and R. Hauser. 2011. Increasing the interval between winter outdoor exercise aggravates agonistic interactions in Hérens cows kept in tie-stalls. Appl. Anim. Behav. Sci. 129:59-66.

CBS. 2015. Dutch Central Bureau for Statistics. Access to pasture in dairy cattle; Pasture area. Accessed Sep. 2, 2015. http://statline. cbs.nl/StatWeb/publication/?VW=TandDM=SLnlandPA=70736 nedandLA $=$ nl.

Cobb, C. J., B. S. Obeidat, M. D. Sellers, A. R. Pepper-Yowell, D. L. Hanson, and M. A. Ballou. 2014. Improved performance and heightened neutrophil responses during the neonatal and weaning periods among outdoor group-housed Holstein calves. J. Dairy Sci. 97:930-939.

Coffey, K. P., J. L. Moyer, F. K. Brazle, and L. W. Lomas. 1992. Amount and diurnal distribution of grazing time by stocker cattle under different tall fescue management strategies. Appl. Anim. Behav. Sci. 33:121-135.

Collins, M. T., V. Eggleston, and E. J. B. Manning. 2010. Successful control of Johne's disease in nine dairy herds: Results of a six-year field trial. J. Dairy Sci. 93:1638-1643.

Cooper, M. D., D. R. Arney, and C. J. Phillips. 2008. The effect of temporary deprivation of lying and feeding on the behaviour and production of lactating dairy cows. Animal 2:275-283.

Costa, J. H. C., R. R. Daros, M. A. G. von Keyserlingk, and D. M Weary. 2014. Complex social housing reduces food neophobia in dairy calves. J. Dairy Sci. 97:7804-7810.

Coulon, M., C. Baudoin, Y. Heyman, and B. L. Deputte. 2011. Cattle discriminate between familiar and unfamiliar conspecifics by using only head visual cues. Anim. Cogn. 14:279-290.

Daros, R. R., J. H. Costa, M. A. von Keyserlingk, M. J. Hötzel, and D. M. Weary. 2014. Separation from the dam causes negative judgement bias in dairy calves. PLoS ONE 9:e98429. http://dx.doi org/10.1371/journal.pone.0098429.

Dawkins, M. S. 1983. Battery hens name their price: Consumer demand theory and the measurement of ethological 'needs'. Anim. Behav. 31:1195-1205.

de Passillé, A. M. 2001. Sucking motivation and related problems in calves. Appl. Anim. Behav. Sci. 72:175-187.

de Passillé, A. M., F. Borderas, and J. Rushen. 2011. Cross-sucking by dairy calves may become a habit or reflect characteristics of individual calves more than milk allowance or weaning. Appl. Anim. Behav. Sci. 133:137-143.

de Passillé, A. M., J. Rushen, J. Ladewig, and C. Petherick. 1996. Dairy calves' discrimination of people based on previous handling. J. Anim. Sci. 74:969-974.

de Passillé, A. M. B., and N. Caza. 1997. Cross-sucking by calves occurs after meals and is reduced when calves suck a dry teat. J. Dairy Sci. 80:229.

De Paula Vieira, A., A. M. de Passillé, and D. M. Weary. 2012. Effects of the early social environment on behavioral responses of dairy calves to novel events. J. Dairy Sci. 95:5149-5155.

De Paula Vieira, A., M. A. G. von Keyserlingk, and D. M. Weary. 2010. Effects of pair versus single housing on performance and behavior of dairy calves before and after weaning from milk. J. Dairy Sci. 93:3079-3085.

DeVries, T. J., M. Vankova, D. M. Veira, and M. A. G. von Keyserlingk. 2007. Usage of mechanical brushes by lactating dairy cows. J. Dairy Sci. 90:2241-2245.

DeVries, T. J., M. A. G. von Keyserlingk, and D. M. Weary. 2004. Effect of feeding space on the inter-cow distance, aggression, and feeding behavior of freestall-housed lactating dairy cows. J. Dairy Sci. 87:1432-1438.

Duve, L. R., and M. B. Jensen. 2011. The level of social contact affects social behaviour in pre-weaned dairy calves. Appl. Anim. Behav. Sci. 135:34-43.

Duve, L. R., D. M. Weary, U. Halekoh, and M. B. Jensen. 2012. The effects of social contact and milk allowance on responses to han- 
dling, play, and social behavior in young dairy calves. J. Dairy Sci. 95:6571-6581.

Edgar, J., S. Held, E. Paul, I. Pettersson, R. I. A. Price, and C. Nicol. 2015. Social buffering in a bird. Anim. Behav. 105:11-19.

Edwards, S. A., and D. M. Broom. 1982. Behavioural interactions of dairy cows with their newborn calves and the effects of parity. Anim. Behav. 30:525-535.

Ellingsen, K., G. J. Coleman, V. Lund, and C. M. Mejdell. 2014. Using qualitative behaviour assessment to explore the link between stockperson behaviour and dairy calf behaviour. Appl. Anim. Behav. Sci. 153:10-17.

Endres, M. I., T. J. DeVries, M. A. G. von Keyserlingk, and D. M. Weary. 2005. Short communication: Effect of feed barrier design on the behavior of loose-housed lactating dairy cows. J. Dairy Sci. $88: 2377-2380$.

European Union. 2008a. Council Directive 2008/120/EC. Laying down minimum standards for the protection of pigs. Accessed Dec. 23, 2015. http://eur-lex.europa.eu/LexUriServ/LexUriServ.do?uri=O J:L:2009:047:0005:0013:EN:PDF.

European Union. 2008b. Council Directive 2008/119/EC, Article 3. Laying down minimum standards for the protection of calves. Accessed Dec. 24, 2015. http://eur-lex.europa.eu/legal-content/EN/ TXT/PDF/?uri=CELEX:32008L0119\&qid=1450978659164\&from $=\mathrm{EN}$.

Færevik, G., M. B. Jensen, and K. E. Bøe. 2006. Dairy calves social preferences and the significance of a companion animal during separation from the group. Appl. Anim. Behav. Sci. 99:205-221.

Flower, F. C., and D. M. Weary. 2001. Effects of early separation on the dairy cow and calf: 2 . Separation at 1 day and 2 weeks after birth. Appl. Anim. Behav. Sci. 70:275-284.

Flower, F. C., and D. M. Weary. 2003. The effects of early separation on the dairy cow and calf. Anim. Welf. 12:339-348.

Fogsgaard, K. K., C. M. Røntved, P. Sørensen, and M. S. Herskin. 2012. Sickness behavior in dairy cows during Escherichia coli mastitis. J. Dairy Sci. 95:630-638

Fraser, D. 2008. Understanding Animal Welfare: The Science in Its Cultural Context. Wiley-Blackwell, Oxford, UK.

Fraser, D., I. J. Duncan, S. A. Edwards, T. Grandin, N. G. Gregory, V. Guyonnet, P. H. Hemsworth, S. M. Huertas, J. M. Huzzey, D. J. Mellor, J. A. Mench, M. Špinka, and H. R. Whay. 2013. General Principles for the welfare of animals in production systems: The underlying science and its application. Vet. J. 198:19-27.

Fraser, D., D. M. Weary, E. A. Pajor, and B. N. Milligan. 1997. A scientific conception of animal welfare that reflects ethical concerns. Anim. Welf. 6:187-205.

Fregonesi, J. A., D. M. Veira, M. A. G. von Keyserlingk, and D. M. Weary. 2007. Effects of bedding quality on lying behavior of dairy cows. J. Dairy Sci. 90:5468-5472

Gaillard, C., R. K. Meagher, M. A. von Keyserlingk, and D. M. Weary. 2014. Social housing improves dairy calves' performance in two cognitive tests. PLoS ONE 9:e90205.

Galindo, F., and D. M. Broom. 2002. The effects of lameness on social and individual behavior of dairy cows. Appl. Anim. Behav. Sci. 5:193-201.

Georg, H., D. Jahn-Falk, and G. U. Brunswick. 2007. Technology against boredom. Landtechnik 62:166-167.

Georg, H., and K. Totschek. 2001. Examining an automatic cow brush for dairy cows. Landtechnik 56:260-261.

Gomez, A., and N. B. Cook. 2010. Time budgets of lactating dairy cattle in commercial freestall herds. J. Dairy Sci. 93:5772-5781.

Grandin, T. 2000. Handling and welfare of livestock in slaughter plants. Pages 409-439 in Livestock Handling and Transport. 2nd ed. T. Grandin, ed. CAB International, Wallingford, UK.

Guillot, F. S. 1981. Susceptibility of Hereford cattle to sheep scab mites after recovery from psoroptic scabies. J. Econ. Entomol. 74:653-657.

Gutmann, A. 2010. Verhalten von Milchkühen bei der Nutzung von fixen gegenüber rotierenden Bürsten. Pages 78-81 in Proc. 24th Internationale Gesellschaft für Nutztierhaltung Conf., Ettenhausen, Switzerland. Forschungsanstalt Agroscope Reckenholz-Tänikon ART. Tänikon, Switzerland.
Gutmann, A. K., M. Špinka, and C. Winckler. 2015. Long-term familiarity creates preferred social partners in dairy cows. Appl. Anim. Behav. Sci. 169:1-8.

Gygax, L., G. Neisen, and B. Wechsler. 2009. Differences between single and paired heifers in residency in functional areas, length of travel path, and area used throughout days 1-6 after integration into a free stall dairy herd. Appl. Anim. Behav. Sci. 120:49-55.

Gygax, L., G. Neisen, and B. Wechsler. 2010. Socio-spatial relationships in dairy cows. Ethology 116:10-23.

Hagen, K., and D. M. Broom. 2004. Emotional reactions to learning in cattle. Appl. Anim. Behav. Sci. 85:203-213.

Haley, D. B., J. Rushen, I. J. Duncan, T. M. Widowski, and A. M. de Passillé. 1998. Butting by calves, Bos taurus, and rate of milk flow. Anim. Behav. 56:1545-1551.

Haskell, M. J., K. Masłowska, D. J. Bell, D. J. Roberts, and F. M. Langford. 2013. The effect of a view to the surroundings and microclimate variables on use of a loafing area in housed dairy cattle. Appl. Anim. Behav. Sci. 147:28-33.

Haskell, M. J., L. J. Rennie, V. A. Bowell, M. J. Bell, and A. B. Lawrence. 2006. Housing system, milk production, and zero-grazing effects on lameness and leg injury in dairy cows. J. Dairy Sci. 89:4259-4266

Heffner, R. S., and H. E. Heffner. 1983. Hearing in large mammals: Horses (Equus caballus) and cattle (Bos taurus). Behav. Neurosci. 97:299-309.

Held, S. D., and M. Spinka. 2011. Animal play and animal welfare. Anim. Behav. 81:891-899.

Hemsworth, P. H. 2003. Human-animal interactions in livestock production. Appl. Anim. Behav. Sci. 81:185-198.

Hemsworth, P. H., G. J. Coleman, J. L. Barnett, and S. Borg. 2000. Relationships between human-animal interactions and productivity of commercial dairy cows. J. Anim. Sci. 78:2821-2831.

Hepola, H., L. Hänninen, P. Pursiainen, V. M. Tuure, L. Syrjälä-Qvist, M. Pyykkönen, and H. Saloniemi. 2006. Feed intake and oral behaviour of dairy calves housed individually or in groups in warm or cold buildings. Livest. Sci. 105:94-104

Hetti Arachchige, A. D., A. D. Fisher, W. J. Wales, M. J. Auldist, M. C. Hannah, and E. C. Jongman. 2014. Space allowance and barriers influence cow competition for mixed rations fed on a feed-pad between bouts of grazing. J. Dairy Sci. 97:3578-3588.

Hillmann, E., B. A. Roth, J. Johns, S. Waiblinger, and K. Barth. 2012. Dam-associated rearing as animal friendly alternative to artificial rearing in dairy cattle. Landbauforsch VTI AG 362:181-183.

Holm, L., M. B. Jensen, and L. L. Jeppesen. 2002. Calves' motivation for access to two different types of social contact measured by operant conditioning. Appl. Anim. Behav. Sci. 79:175-194.

Hoyer, B. H. 2013. Environmental enrichment-Strategies to improve the housing conditions of breeding bulls, impact on time budget, physical activity, rumination, sexual behavior and semen quality. $\mathrm{PhD}$ Thesis. University of Veterinary Medicine, Hannover, Germany.

Hudson, S. J., and M. M. Mullord. 1977. Investigations of maternal bonding in dairy cattle. Appl. Anim. Ethol. 3:271-276.

Hughes, B. O., and I. J. H. Duncan. 1988. The notion of ethological 'need', models of motivation and animal welfare. Anim. Behav. 36:1696-1707.

Hutchings, M. R., S. Athanasiadou, I. Kyriazakis, and I. J. Gordon. 2003. Can animals use foraging behaviour to combat parasites? Proc. Nutr. Soc. 62:361-370.

Ikeda, Y., and Y. Ishii. 2008. Recognition of two psychological conditions of a single cow by her voice. Comput. Electron. Agric. 62:67-72

Inglis, I. R., B. Forkman, and J. Lazarus. 1997. Free food or earned food? A review and fuzzy model of contrafreeloading. Anim. Behav. 53:1171-1191.

Ishiwata, T., K. Uetake, R. J. Kilgour, Y. Eguchi, and T. Tanaka. 2007. Oral behaviors of beef steers in pen and pasture environments. J. Appl. Anim. Welf. Sci. 10:185-192.

Israeli Dairy Reform. 1999-2008. Accessed Dec. 23, 2015. www.milk. org.il/info/env/docs/english.pdf. 
Jensen, M. B. 2001. A note on the effect of isolation during testing and length of previous confinement on locomotor behaviour during open-field test in dairy calves. Appl. Anim. Behav. Sci. 70:309-315.

Jensen, M. B. 2003. The effects of feeding method, milk allowance and social factors on milk feeding behaviour and cross-sucking in group housed dairy calves. Appl. Anim. Behav. Sci. 80:191-206.

Jensen, M. B., A. M. de Passillé, M. A. G. von Keyserlingk, and J. Rushen. 2008. A barrier can reduce competition over teats in pairhoused milk-fed calves. J. Dairy Sci. 91:1607-1613.

Jensen, M. B., L. R. Duve, and D. M. Weary. 2015a. Pair housing and enhanced milk allowance increase play behavior and improve performance in dairy calves. J. Dairy Sci. 98:2568-2575.

Jensen, M. B., M. S. Herskin, P. T. Thomsen, B. Forkman, and H Houe. 2015b. Preferences of lame cows for type of surface and level of social contact in hospital pens. J. Dairy Sci. 98:4552-4559.

Jensen, M. B., and L. E. Larsen. 2014. Effects of level of social contact on dairy calf behavior and health. J. Dairy Sci. 97:5035-5044.

Jensen, M. B., K. S. Vestergaard, and C. C. Krohn. 1998. Play behaviour in dairy calves kept in pens: the effect of social contact and space allowance. Appl. Anim. Behav. Sci. 56:97-108.

Jensen, M. B., K. S. Vestergaard, C. C. Krohn, and L. Munksgaard. 1997. Effect of single versus group housing and space allowance on responses of calves during open-field tests. Appl. Anim. Behav. Sci. 54:109-121.

Jensen, M. B., and D. Weary. 2013. Group housing and milk feeding of dairy calves. Pages 179- 189 in Proc. 25th Western Canadian Dairy Seminar, Advances in Dairy Technology. University of Alberta, Edmonton. Canada.

Jensen, P., B. Recen, and I. Ekesbo. 1988. Preference of loose housed dairy cows for two different cubicle floor coverings. Swed. J. Agric. Res. 18:141-146.

Johns, J., A. Patt, and E. Hillmann. 2015. Do bells affect behaviour and heart rate variability in grazing dairy cows? PLoS ONE 10:e0131632

Johnsen, J. F., A. Marie de Passille, C. M. Mejdell, K. E. Bøe, A. M. Grøndahl, A. Beaver, J. Rushen, and D. M. Weary. 2015. The effect of nursing on the cow-calf bond. Appl. Anim. Behav. Sci. 163:50-57.

Kalber, T., and K. Barth. 2014. Practical implications of suckling systems for dairy calves in organic production systems-A review. Appl. Agric. Forestry. Res. 64:45-58.

Keil, N. M., L. Audigé, and W. Langhans. 2000. Factors associated with intersucking in Swiss dairy heifers. Prev. Vet. Med. 45:305323.

Keil, N. M., T. U. Wiederkehr, K. Friedli, and B. Wechsler. 2006. Effects of frequency and duration of outdoor exercise on the prevalence of hock lesions in tied Swiss dairy cows. Prev. Vet. Med. 74:142-153.

Kikusui, T., J. T. Winslow, and Y. Mori. 2006. Social buffering: Relief from stress and anxiety. Philos. Trans. R. Soc. Lond. B Biol. Sci. 361:2215-2228.

Kilgour, R., and C. Dalton. 1984. Livestock Behaviour: A Practical Guide. Granada Publishing Ltd., London, UK.

Kıyıcı, J. M., R. Koçygt, and N. Tüzemen. 2013. The effect of classical music on milk production, milk components and milking characteristics of Holstein Friesian. J. Tekirdag Agric. Fac. 10:74-81.

Kohari, D., T. Kosako, M. Fukasawa, and H. Tsukada. 2007. Effect of environmental enrichment by providing trees as rubbing objects in grassland: Grazing cattle need tree-grooming. Anim. Sci. J. $78: 413-416$

Krohn, C. C. 1994. Behaviour of dairy cows kept in extensive (loose housing/pasture) or intensive (tie stall) environments. III. Grooming, exploration and abnormal behaviour. Appl. Anim. Behav. Sci. 42:73-86.

Laister, S., B. Stockinger, A. M. Regner, K. Zenger, U. Knierim, and C. Winckler. 2011. Social licking in dairy cattle -Effects on heart rate in performers and receivers. Appl. Anim. Behav. Sci. 130:8190.

Langbein, J., K. Siebert, and G. Nürnberg. 2009. On the use of an automated learning device by group-housed dwarf goats: Do goats seek cognitive challenges? Appl. Anim. Behav. Sci. 120:150-158.
Launchbaugh, K. L. 1995. Effects of neophobia and aversions of feed intake: Why feedlot cattle sometimes refuse to eat nutritious feed. Pages 36-48 in Symposium: Intake by Feedlot Cattle. Okla. Agric. Exp. Sta., Stillwater, OK.

Le Neindre, P. 1989. Influence of rearing conditions and breed on social behaviour and activity of cattle in novel environments. Appl. Anim. Behav. Sci. 23:129-140.

Lensink, B. J., S. Raussi, X. Boivin, M. Pyykkönen, and I. Veissier. 2001. Reactions of calves to handling depend on housing condition and previous experience with humans. Appl. Anim. Behav. Sci. 70:187-199.

Lidfors, L. M., D. Moran, J. Jung, P. Jensen, and H. Castren. 1994. Behaviour at calving and choice of calving place in cattle kept in different environments. Appl. Anim. Behav. Sci. 42:11-28.

Loberg, J., and L. M. Lidfors. 2001. Effect of milkflow rate and presence of floating nipple on abnormal sucking between dairy calves. Appl. Anim. Behav. Sci. 72:189-199.

Loberg, J., E. Telezhenko, C. Bergsten, and L. Lidfors. 2004. Behaviour and claw health in tied dairy cows with varying access to exercise in an outdoor paddock. Appl. Anim. Behav. Sci. 89:1-16.

Losinger, W. C., and A. Heinrichs. 1997. Management practices associated with high mortality among preweaned dairy heifers. J. Dairy Res. 64:1-11.

Lürzel, S., C. Münsch, I. Windschnurer, A. Futschik, R. Palme, and S. Waiblinger. 2015. The influence of gentle interactions on avoidance distance towards humans, weight gain and physiological parameters in group-housed dairy calves. Appl. Anim. Behav. Sci. 172:9-16. http://dx.doi.org/10.1016/j.applanim.2015.09.004

Mandel, R., H. R. Whay, C. J. Nicol, and E. Klement. 2013. The effect of food location, heat load, and intrusive medical procedures on brushing activity in dairy cows. J. Dairy Sci. 96:6506-6513.

Manninen, E., A. M. de Passillé, J. Rushen, M. Norring, and H. Saloniemi. 2002. Preferences of dairy cows kept in unheated buildings for different kind of cubicle flooring. Appl. Anim. Behav. Sci. 75:281-292.

Manteuffel, G., J. Langbein, and B. Puppe. 2009. From operant learning to cognitive enrichment in farm animal housing: bases and applicability. Anim. Welf. 18:87-95.

Manteuffel, G., B. Puppe, and P. C. Schön. 2004. Vocalization of farm animals as a measure of welfare. Appl. Anim. Behav. Sci. $88: 163-182$

March, M. D., M. J. Haskell, M. G. G. Chagunda, F. M. Langford, and D. J. Roberts. 2014. Current trends in British dairy management regimens. J. Dairy Sci. 97:7985-7994.

Marchant-Forde, J. N., R. M. Marchant-Forde, and D. M. Weary. 2002. Responses of dairy cows and calves to each other's vocalisations after early separation. Appl. Anim. Behav. Sci. 78:19-28.

Mason, G. J., and C. C. Burn. 2011. Behavioural restriction. Pages 98 119 in Animal Welfare. 2nd ed. CAB International, Oxford, UK.

McCowan, B., A. M. DiLorenzo, S. Abichandani, C. Borelli, and J. S. Cullor. 2002. Bioacoustic tools for enhancing animal management and productivity: Effects of recorded calf vocalizations on milk production in dairy cows. Appl. Anim. Behav. Sci. 77:13-20.

McFarland, D. 1999. Animal Behaviour. 3rd ed. Addison Wesley Longman, Reading, UK.

Meehan, C. L., and J. A. Mench. 2007. The challenge of challenge: Can problem-solving opportunities enhance animal welfare? Appl. Anim. Behav. Sci. 102:246-261.

Mendl, M., O. H. Burman, and E. S. Paul. 2010. An integrative and functional framework for the study of animal emotion and mood. Proc. Biol. Sci. 277:2895-2904.

Miller, K., and D. G. M. Wood-Gush. 1991. Some effects of housing on the social behaviour of dairy cows. Anim. Prod. 53:271-278.

Mintline, E. M., M. Stewart, A. R. Rogers, N. R. Cox, G. A. Verkerk, J. M. Stookey, J. R. Webster, and C. B. Tucker. 2013. Play behavior as an indicator of animal welfare: Disbudding in dairy calves. Appl. Anim. Behav. Sci. 144:22-30.

Mitchell, K. D., J. M. Stookey, D. K. Laturnas, J. M. Watts, D. B Haley, and T. Huyde. 2004. The effects of blindfolding on behavior and heart rate in beef cattle during restraint. Appl. Anim. Behav. Sci. 85:233-245. 
Morgan, K. N., and C. T. Tromborg. 2007. Sources of stress in captivity. Appl. Anim. Behav. Sci. 102:262-302.

Mounier, L., I. Veissier, S. Andanson, E. Delval, and A. Boissy. 2006. Mixing at the beginning of fattening moderates social buffering in beef bulls. Appl. Anim. Behav. Sci. 96:185-200.

NAHMS. 2010. Dairy 2007. Facility Characteristics and Cow Comfort on U.S. Dairy Operations. USDA:APHIS:VS:CEAH, Fort Collins, CO. Accessed Oct. 3, 2015. http://www.aphis.usda.gov/animal_ health/nahms/dairy/downloads/dairy07/Dairy07_ir_Facilities. pdf.

Neisen, G., B. Wechsler, and L. Gygax. 2009. Effects of the introduction of single heifers or pairs of heifers into dairy-cow herds on the temporal and spatial associations of heifers and cows. Appl. Anim. Behav. Sci. 119:127-136.

Newberry, R. C. 1993. The space-time continuum, and its relevance to farm animals. Ethologia 3:219-234.

Newberry, R. C. 1995. Environmental enrichment: Increasing the biological relevance of captive environments. Appl. Anim. Behav. Sci. 44:229-243.

Newberry, R. C., and J. C. Swanson. 2008. Implications of breaking mother-young social bonds. Appl. Anim. Behav. Sci. 110:3-23.

Newby, N. C., T. F. Duffield, D. L. Pearl, K. E. Leslie, S. J. LeBlanc, and M. A. von Keyserlingk. 2013. Use of a mechanical brush by Holstein dairy cattle around parturition. J. Dairy Sci. 96:23392344.

Nicol, C. J., G. Caplen, J. Edgar, and W. J. Browne. 2009. Associations between welfare indicators and environmental choice in laying hens. Anim. Behav. 78:413-424.

Ninomiya, S. 2014. Satisfaction of farm animal behavioral needs in behaviorally restricted systems: Reducing stressors and environmental enrichment. Anim. Sci. J. 85:634-638.

Ninomiya, S., and S. Sato. 2009. Effects of 'Five freedoms' environmental enrichment on the welfare of calves reared indoors. Anim. Sci. J. 80:347-351.

Ninomiya, S., and S. Sato. 2011. The assessment of the effect of presenting a companion's face picture on social isolation stress using saliva sampling in cows. Anim. Sci. J. 82:787-791.

Nitrates Action Programme and Phosphorus Regulations. 2015-2018. Accessed Sept. 15, 2015. http://www.doeni.gov.uk/niea/waterhome/agri_regs/nitrates-and-phosphorus-regulations-2015-2018. htm.

Norring, M., E. Manninen, A. M. de Passillé, J. Rushen, L. Munksgaard, and H. Saloniemi. 2008. Effects of sand and straw bedding on the lying behavior, cleanliness, and hoof and hock injuries of dairy cows. J. Dairy Sci. 91:570-576.

Norring, M., E. Manninen, A. M. de Passillé, J. Rushen, and H. Saloniemi. 2010. Preferences of dairy cows for three stall surface materials with small amounts of bedding. J. Dairy Sci. 93:70-74.

O'Connell, N. E., H. C. Wicks, A. F. Carson, and M. A. McCoy. 2008. Influence of post-calving regrouping strategy on welfare and performance parameters in dairy heifers. Appl. Anim. Behav. Sci. 114:319-329.

Oltenacu, P. A., and B. Algers. 2005. Selection for increased production and the welfare of dairy cows: are new breeding goals needed? Ambio 34:311-315.

Pajor, E. A., J. Rushen, and A. M. B. de Passillé. 2003. Dairy cattle's choice of handling treatments in a Y-maze. Appl. Anim. Behav. Sci. 80:93-107.

Piller, C. A., J. M. Stookey, and J. M. Watts. 1999. Effects of mirrorimage exposure on heart rate and movement of isolated heifers Appl. Anim. Behav. Sci. 63:93-102.

Pilz, M., C. Fischer-Tenhagen, G. Thiele, H. Tinge, F. Lotz, and W. Heuwieser. 2012. Behavioural reactions before and during vaginal examination in dairy cows. Appl. Anim. Behav. Sci. 138:18-27.

Pollock, W. E., and J. F. Hurnik. 1978. Effect of calf calls on rate of milk release of dairy cows. J. Dairy Sci. 61:1624-1626.

Popescu, S., C. Borda, E. A. Diugan, M. Spinu, I. S. Groza, and C. D. Sandru. 2013. Dairy cows welfare quality in tie-stall housing system with or without access to exercise. Acta Vet. Scand. 55:43.
Probst, J. K., A. S. Neff, F. Leiber, M. Kreuzer, and E. Hillmann. 2012. Gentle touching in early life reduces avoidance distance and slaughter stress in beef cattle. Appl. Anim. Behav. Sci. 139:42-49.

Proctor, H. S., and G. Carder. 2014. Can ear postures reliably measure the positive emotional state of cows? Appl. Anim. Behav. Sci. 161:20-27.

Proctor, H. S., and G. Carder. 2015a. Measuring positive emotions in cows: Do visible eye whites tell us anything? Physiol. Behav. 147:1-6.

Proctor, H. S., and G. Carder. 2015b. Nasal temperatures in dairy cows are influenced by positive emotional state. Physiol. Behav. 138:340-344

Proudfoot, K. L., M. B. Jensen, D. M. Weary, and M. A. G. von Keyserlingk. 2014b. Dairy cows seek isolation at calving and when ill. J. Dairy Sci. 97:2731-2739.

Proudfoot, K. L., D. M. Weary, and M. A. G. von Keyserlingk. 2014a. Maternal isolation behavior of Holstein dairy cows kept indoors. J. Anim. Sci. 92:277-281.

Rault, J. L. 2012. Friends with benefits: Social support and its relevance for farm animal welfare. Appl. Anim. Behav. Sci. 136:1-14.

Raussi, S., S. Niskanen, J. Siivonen, L. Hänninen, H. Hepola, L. Jauhiainen, and I. Veissier. 2010. The formation of preferential relationships at early age in cattle. Behav. Processes 84:726-731.

Rauw, W. M., E. Kanis, E. N. Noordhuizen-Stassen, and F. J. Grommers. 1998. Undesirable side effects of selection for high production efficiency in farm animals: A review. Livest. Prod. Sci. 56:15-33.

Regula, G., J. Danuser, B. Spycher, and B. Wechsler. 2004. Health and welfare of dairy cows in different husbandry systems in Switzerland. Prev. Vet. Med. 66:247-264.

Reijs, J. W., C. H. G. Daatselaar, J. F. M. Helming, J. Jager, and A. C. G. Beldman. 2013. Grazing dairy cows in north-west Europe. Economic farm performance and future developments with emphasis on the Dutch situation. Report of the Landbouw Economisch Instituut (LEI). LEI Wageningen UR, Wageningen, the Netherlands.

Rioja-Lang, F. C., D. J. Roberts, S. D. Healy, A. B. Lawrence, and M. J. Haskell. 2009. Dairy cows trade-off feed quality with proximity to a dominant individual in Y-maze choice tests. Appl. Anim. Behav. Sci. 117:159-164.

Roth, B. A., K. Barth, L. Gygax, and E. Hillmann. 2009. Influence of artificial vs. mother-bonded rearing on sucking behaviour, health and weight gain in calves. Appl. Anim. Behav. Sci. 119:143-150.

Rushen, J., L. Munksgaard, A. M. B. de Passillé, M. B. Jensen, and K. Thodberg. 1998. Location of handling and dairy cows' responses to people. Appl. Anim. Behav. Sci. 55:259-267.

Rushen, J., L. Munksgaard, P. G. Marnet, and A. M. de Passillé. 2001. Human contact and the effects of acute stress on cows at milking. Appl. Anim. Behav. Sci. 73:1-14

Rushen, J., A. A. Taylor, and A. M. de Passillé. 1999. Domestic animals' fear of humans and its effect on their welfare. Appl. Anim. Behav. Sci. 65:285-303.

Sambrook, T. D., and H. M. Buchanan-Smith. 1997. Control and complexity in novel object enrichment. Anim. Welf. 6:207-216

Sandem, A. I. B. O. Braastad, and K. E. Bøe. 2002. Eye white may indicate emotional state on a frustration-contentedness axis in dairy cows. Appl. Anim. Behav. Sci. 79:1-10.

Sandem, A. I., A. M. Janczak, and B. O. Braastad. 2004. A short note on effects of exposure to a novel stimulus (umbrella) on behaviour and percentage of eye-white in cows. Appl. Anim. Behav. Sci. 89:309-314

Sato, S., S. Sako, and A. Maeda. 1991. Social licking patterns in cattle (Bos taurus): Influence of environmental and social factors. Appl. Anim. Behav. Sci. 32:3-12.

Sato, S., K. Tarumizu, and K. Hatae. 1993. The influence of social factors on allogrooming in cows. Appl. Anim. Behav. Sci. 38:235-244.

Schirmann, K., N. Chapinal, D. M. Weary, W. Heuwieser, and M. A. G. von Keyserlingk. 2011. Short-term effects of regrouping on behavior of prepartum dairy cows. J. Dairy Sci. 94:2312-2319.

Schloeth, R. 1961. Das socialleben des carmargue Rindes. Z. Tierpsychol. 18:574-627. 
Schukken, Y. H., and G. D. Young. 2009. Field study on milk production and mastitis effect of the DeLaval Swinging Cow Brush. DeLaval Swinging Cow Brush Study Final Report. DeLaval, Tumba, Sweden.

Schütz, K. E., K. V. Clark, N. R. Cox, L. R. Matthews, and C. B. Tucker. 2010. Responses to short-term exposure to simulated rain and wind by dairy cattle: Time budgets, shelter use, body temperature and feed intake. Anim. Welf. 19:375-383.

Schütz, K. E., M. Hawke, J. R. Waas, L. M. McLeay, E. A. M. Bokkers, C. G. van Reenen, J. R. Webster, and M. Stewart. 2012. Effects of human handling during early rearing on the behaviour of dairy calves. Anim. Welf. 21:19-26.

Shyne, A. 2006. Meta-analytic review of the effects of enrichment on stereotypic behavior in zoo mammals. Zoo Biol. 25:317-337.

Spinka, M., and Wemelsfelder, F. 2011. Environmental challenge and animal agency. Pages 27-43 in Animal Welfare. 2nd ed. CABI International, Wallingford, UK.

Stanford, K., D. Croy, S. J. Bach, G. L. Wallins, H. Zahiroddini, and T. A. McAllister. 2005. Ecology of Escherichia coli O157:H7 in commercial dairies in Southern Alberta. J. Dairy Sci. 88:4441-4451.

Stanford, K., R. Silasi, T. A. McAllister, and K. S. SchwartzkopfGenswein. 2009. Behavior of feedlot cattle affects voluntary oral and physical interactions with manila ropes. J. Anim. Sci. 87:296303.

Stewart, M., H. M. Shepherd, J. R. Webster, J. R. Waas, L. M. McLeay, and K. E. Schütz. 2013. Effect of previous handling experiences on responses of dairy calves to routine husbandry procedures. Animal 7:828-833.

Svensson, C., J. Hultgren, and P. A. Oltenacu. 2006. Morbidity in 3-7-month-old dairy calves in south-western Sweden, and risk factors for diarrhoea and respiratory disease. Prev. Vet. Med. 74:162179

Svensson, C., and P. Liberg. 2006. The effect of group size on health and growth rate of Swedish dairy calves housed in pens with automatic milk-feeders. Prev. Vet. Med. 73:43-53.

Svensson, C., K. Lundborg, U. Emanuelson, and S. O. Olsson. 2003 Morbidity in Swedish dairy calves from birth to 90 days of age and individual calf-level risk factors for infectious diseases. Prev. Vet. Med. 58:179-197.

Talebi, A., M. A. G. von Keyserlingk, E. Telezhenko, and D. M. Weary. 2014. Reduced stocking density mitigates the negative effects of regrouping in dairy cattle. J. Dairy Sci. 97:1358-1363.

Taylor, A. A., and H. Davis. 1998. Individual humans as discriminative stimuli for cattle (Bos taurus). Appl. Anim. Behav. Sci. 58:13-21.

Terlouw, E. M., A. Boissy, and P. Blinet. 1998. Behavioural responses of cattle to the odours of blood and urine from conspecifics and to the odour of faeces from carnivores. Appl. Anim. Behav. Sci. $57: 9-21$.

Thomas, T. J., D. M. Weary, and M. C. Appleby. 2001. Newborn and 5-week-old calves vocalize in response to milk deprivation. Appl. Anim. Behav. Sci. 74:165-173.

Toaff-Rosenstein, R. L., L. J. Gershwin, A. J. Zanella, and C. B. Tucker. 2014. Characterizing the BRD sickness response-Opportunities for improved disease detection. 4th Int. Symp. Beef Cattle Welfare, Ames, IA. Iowa State University, Ames.

Tucker, C. B. 2009. Behaviour of cattle. Page 1151 in The Ethology of Domestic Animals: An Introductory Text. P. Jensen, ed. CAB International, Wallingford, UK.

Tucker, C. B., D. M. Weary, and D. Fraser. 2003. Effects of three types of free-stall surfaces on preferences and stall usage by dairy cows J. Dairy Sci. 86:521-529.

Tuyttens, F. A. M. 2005. The importance of straw for pig and cattle welfare: A review. Appl. Anim. Behav. Sci. 92:261-282.

Ude, G., H. Georg, and A. Schwalm. 2011. Reducing milk-induced cross-sucking of group housed calves by an environmentally enriched post feeding area. Livest. Sci. 138:293-298.

Uetake, K., J. F. Hurnik, and L. Johnson. 1997. Effect of music on voluntary approach of dairy cows to an automatic milking system. Appl. Anim. Behav. Sci. 53:175-182.

Val-Laillet, D., V. Guesdon, M. A. von Keyserlingk, A. M. de Passillé, and J. Rushen. 2009. Allogrooming in cattle: Relationships between social preferences, feeding displacements and social dominance. Appl. Anim. Behav. Sci. 116:141-149.

Val-Laillet, D., D. M. Veira, and M. A. G. von Keyserlingk. 2008. Dominance in free-stall-housed dairy cattle is dependent upon resource. J. Dairy Sci. 91:3922-3926.

Valníčková, B., I. Stěhulová, R. Šárová, and M. Špinka. 2015. The effect of age at separation from the dam and presence of social companions on play behavior and weight gain in dairy calves. J. Dairy Sci. 98:5545-5556.

van de Weerd, H. A., and J. E. Day. 2009. A review of environmental enrichment for pigs housed in intensive housing systems. Appl. Anim. Behav. Sci. 116:1-20.

Van Vuuren, A. M., and A. Van den Pol-van Dasselaar. 2006. Grazing systems and feed supplementation. Pages 85-101 in Fresh Herbage for Dairy Cattle. A. Elgersma, J. Dijkstra, and S. Tamminga, ed. Springer, Wageningen, the Netherlands.

Vaughan, A., A. M. de Passillé, J. Stookey, and J. Rushen. 2014 Operant conditioning of urination by calves. Appl. Anim. Behav. Sci. 158:8-15.

Veerkamp, R. F., J. J. Windig, M. P. L. Calus, W. Ouweltjes, Y. De Haas, and B. Beerda. 2009. Selection for high production in dairy cattle. Pages 243-260 in Resource Allocation Theory Applied to Farm Animal Production. W. M. Rauw, ed. CAB International, Wallingford, UK.

Veissier, I., S. Andanson, H. Dubroeucq, and D. Pomiès. 2008. The motivation of cows to walk as thwarted by tethering. J. Anim. Sci $86: 2723-2729$

Ventura, B. A., M. A. G. Von Keyserlingk, C. A. Schuppli, and D. M. Weary. 2013. Views on contentious practices in dairy farming: The case of early cow-calf separation. J. Dairy Sci. 96:6105-6116.

von Keyserlingk, M. A. G., D. Olenick, and D. M. Weary. 2008. Acute behavioral effects of regrouping dairy cows. J. Dairy Sci. 91:10111016.

Wagner, K., K. Barth, E. Hillmann, R. Palme, A. Futschik, and S. Waiblinger. 2013. Mother rearing of dairy calves: Reactions to isolation and to confrontation with an unfamiliar conspecific in a new environment. Appl. Anim. Behav. Sci. 147:43-54.

Wagner, K., K. Barth, R. Palme, A. Futschik, and S. Waiblinger. 2012. Integration into the dairy cow herd: Long-term effects of mother contact during rearing the first twelve weeks of life. Appl. Anim. Behav. Sci. 141:117-129.

Wagner, K., D. Seitner, K. Barth, R. Palme, A. Futschik, and S. Waiblinger. 2015. Effects of mother versus artificial rearing during the first 12 weeks of life on challenge responses of dairy cows. Appl. Anim. Behav. Sci. 164:1-11.

Waiblinger, S., X. Boivin, V. Pedersen, M. V. Tosi, A. M. Janczak, E. K. Visser, and R. B. Jones. 2006. Assessing the human-animal relationship in farmed species: A critical review. Appl. Anim. Behav. Sci. 101:185-242.

Waiblinger, S., C. Menke, and G. Coleman. 2002. The relationship between attitudes, personal characteristics and behaviour of stockpeople and subsequent behaviour and production of dairy cows. Appl. Anim. Behav. Sci. 79:195-219.

Waiblinger, S. C. Menke, J. Korff, and A. Bucher. 2004. Previous handling and gentle interactions affect behaviour and heart rate of dairy cows during a veterinary procedure. Appl. Anim. Behav. Sci. 85:31-42.

Warnick, V. D., C. W. Arave, and C. H. Mickelsen. 1977. Effects of group, individual, and isolated rearing of calves on weight gain and behavior. J. Dairy Sci. 60:947-953.

Waynert, D. F., J. M. Stookey, K. S. Schwartzkopf-Genswein, J. M. Watts, and C. S. Waltz. 1999. The response of beef cattle to noise during handling. Appl. Anim. Behav. Sci. 62:27-42.

Weary, D. M., and B. Chua. 2000. Effects of early separation on the dairy cow and calf: 1 . Separation at $6 \mathrm{~h}, 1$ day and 4 days after birth. Appl. Anim. Behav. Sci. 69:177-188.

Webb, L. E., M. B. Jensen, B. Engel, C. G. van Reenen, W. J. J. Gerrits, I. J. M. de Boer, and E. A. M. Bokkers. 2014. Chopped or long roughage: What do calves prefer? Using cross point analysis of double demand functions. PLoS ONE 9:e88778. 
Wechsler, B., and S. E. Lea. 2007. Adaptation by learning: Its significance for farm animal husbandry. Appl. Anim. Behav. Sci. 108:197-214

Wells, D. L. 2009. Sensory stimulation as environmental enrichment for captive animals: A review. Appl. Anim. Behav. Sci. 118:1-11.

Wells, S. J., L. P. Garber, and G. W. Hill. 1997. Health status of preweaned dairy heifers in the United States. Prev. Vet. Med. 29:185-199.

Westerath, H. S., L. Gygax, and E. Hillmann. 2014. Are special feed and being brushed judged as positive by calves? Appl. Anim. Behav. Sci. 156:12-21.

Wilson, S. C., F. M. Mitlöhner, J. Morrow-Tesch, J. W. Dailey, and J. J. McGlone. 2002. An assessment of several potential enrichment devices for feedlot cattle. Appl. Anim. Behav. Sci. 76:259-265.
Winsten, J. R., C. D. Kerchner, A. Richardson, A. Lichau, and J. M. Hyman. 2010. Trends in the Northeast dairy industry: Large-scale modern confinement feeding and management-intensive grazing. J. Dairy Sci. 93:1759-1769.

Wood-Gush, D. G. M., K. Hunt, K. Carson, and S. G. C. Dennison. 1984. The early behaviour of suckler calves in the field. Biol. Behav. 9:295-306

Wredle, E., L. Munksgaard, and E. Spörndly. 2006. Training cows to approach the milking unit in response to acoustic signals in an automatic milking system during the grazing season. Appl. Anim. Behav. Sci. 101:27-39.

Wredle, E., J. Rushen, A. M. de Passille, and L. Munksgaard. 2004. Training cattle to approach a feed source in response to auditory signals. Can. J. Anim. Sci. 84:567-572. 